\title{
Synthesis of 2-Arylpyridines and 2-Arylbipyridines via Photoredox-Induced Meerwein Arylation with in-situ Diazotization of Anilines
}

\author{
Wided Hagui and Jean-François Soulé*
}

Univ Rennes, CNRS UMR6226, F-3500Rennes, France jean-francois.soule@univ-rennes1.fr

\begin{abstract}
We report herein a sustainable method for the preparation of 2-arylpyridines through $\mathrm{C}-\mathrm{H}$ arylation of pyridines using in-situ formed diazonium salts (from commercially available aromatic amines) in the presence of a photoredox catalyst under blue LEDs irradiation. The reaction is tolerant to a wide range of functional groups (e.g., halogen, nitrile, formyl, acetyl, ester). Applications to the $\mathrm{C}-\mathrm{H}$ bond arylation of bipyridine ligands is also presented.
\end{abstract}

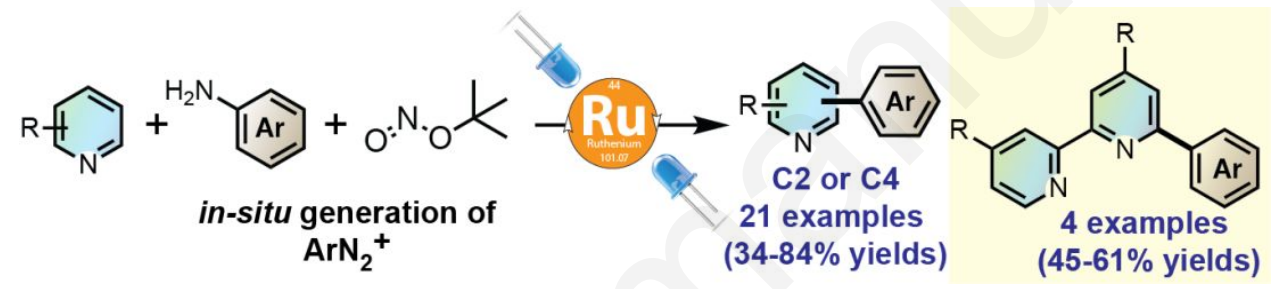

\section{Introduction}

The 2-arylpyridine derivatives are one of the essential scaffolds for the preparation of organometallic complexes with catalytic or material uses (Figure1). For example, $f a c-\operatorname{Ir}(\mathrm{ppy})_{3}$ with three 2-phenylpyridine is often employed as photoredox catalyst. ${ }^{1}$ FIrPic with two 2-(2,4difluorophenyl)pyridine is an highly phosphorescent bis-cyclometalated iridium complexes employed in OLEDs' manufacture. ${ }^{2}$ Moreover, 2-arylpyridine is a common unit widely embedded in pharmaceutical drugs. For example, Enpiroline is an antimalarial agent.
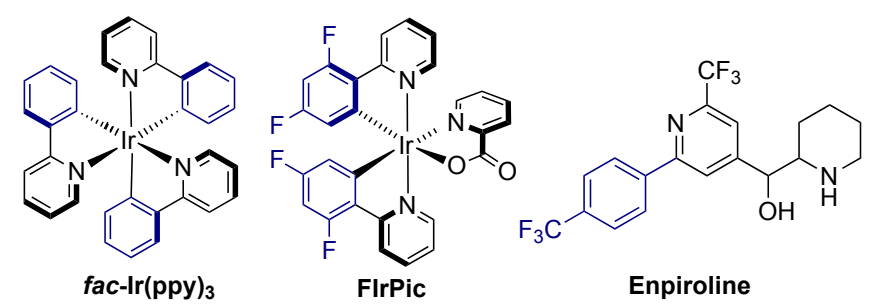

Figure 1. Representative 2-Arylpyridine in Organometallics and Pharmaceuticals.

Traditionally, 2-arylpyridines were synthesized from 2-halopyridines through cross-coupling reactions with aryl pseudo-halides as coupling partners in the presence of palladium catalysts ${ }^{3}$ 
or from metalated pyridines and aryl pseudo-halides. ${ }^{4}$ Among these protocols, the use of 2(tributylstannyl)pyridine remains the most employed starting materials, albeit it is a hazardous and harmful reagent (Figure 2a). More sustainable approaches based on transition-metal catalyzed $\mathrm{C}-\mathrm{H}$ bond arylation of pyridines were often carried out under harsh reaction conditions and displayed a poor substrate scope, ${ }^{5}$ or required the prior oxidation of pyridines to $\mathrm{N}$-oxide pyridines. ${ }^{6}$ Recently, photoredox catalysis has emerged as an eco-friendly alternative to build $\mathrm{C}-\mathrm{C}$ bond from $\mathrm{C}\left(\mathrm{sp}^{2}\right)-\mathrm{H}$ bond under mild reaction conditions. ${ }^{7}$ In 2014 , Xue and coworkers reported the photoredox-catalyzed $\mathrm{C}-\mathrm{H}$ bond arylation of pyridine derivatives at $\mathrm{C} 2$ or/and $\mathrm{C} 4$ positions with aryldiazonium salts using $\mathrm{Ru}(\mathrm{bpy}) 3_{3}{ }^{2+}$ (Figure $\left.2 \mathrm{~b}\right){ }^{8}$ This Merweintype arylation of pyridines was also developed using different photosensitizers. ${ }^{9}$ In 2017 , Heinrich and co-workers demonstrated that the arylation of heteroarenes with aryldiazonium salts could also proceed in the absence of an external photosensitizer. ${ }^{10}$ The reaction involves the formation of charge-transfer complexes ${ }^{11}$ between the electron-poor aryl diazonium salts with electron-rich (hetero)aromatics. In the case of pyridine, only 3-hydroxypyridine has been arylated owing to its specific electronic nature, which allows the formation of charge-transfer complexes with aryl diazonium and is a good aryl radical acceptor. Besides the regioselectivity issue due to the low control of the radical additions, an additional challenge is the handling of the potentially unstable aryldiazonium precursors. In 2014, to avoid the use of such hazardous chemicals and employed commercially available chemicals, Martín, Carrillo, and co-workers have developed $\mathrm{C}-\mathrm{H}$ bond arylation of (hetero) arenes using in-situ diazotization from anilines with tert-butyl that is promoted by catalytic amounts of L-ascorbic acid, with no heating or irradiation. ${ }^{12}$ However, these protocols were limited to the direct arylation of 5-membered ring heteroarenes, electron-rich arenes and $N$-oxide pyridines (Figure $2 \mathrm{c}$ ). The reaction can be also promoted by a mild base $\left(\mathrm{Na}_{2} \mathrm{CO}_{3}\right),{ }^{13}$ or polyamine. ${ }^{14}$ Later, Horan's group showed that the reaction can also proceed at $40{ }^{\circ} \mathrm{C}$ in the absence of L-ascorbic acid. ${ }^{15}$ In 2015, Frutos, Kappe, and co-workers also demonstrated that the $\mathrm{C}-\mathrm{H}$ bond arylation of (hetero) arenes using in-situ diazotization from anilines with tert-butyl could proceeded at room temperate under visiblelight irradiation. ${ }^{16}$ Again, the scope of the reaction is limited to heteroarenes, electron-rich arenes and $N$-oxide pyridines.

To the best of our knowledge, there is no example of (photoredox-initiated) $\mathrm{C}-\mathrm{H}$ bond arylation pyridines using anilines trough the in-situ generation of diazonium slats, albeit it might provide practical and sustainable access to 2-arylpyridine derivatives in one-step from commercially available starting materials (Figure $2 \mathrm{~b}$ ). In addition, there is no example of direct arylation of 
bipyridines (even using aryldiazonium salts) although they are useful precursors for the preparation of $\mathrm{CNN}$-cyclometalated complexes.
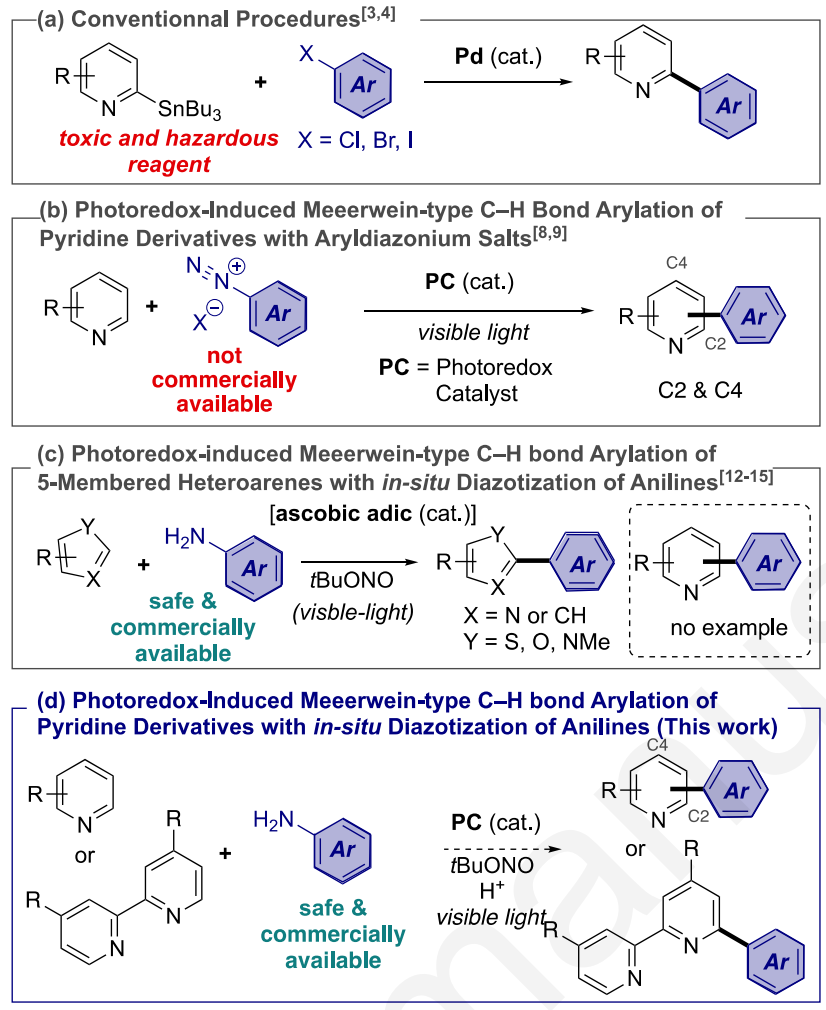

Figure 2. Synthesis of 2-Arylpyridines

\section{Results \& Discussion}

Firstly, we selected 4-cyanopyridine and 4-aminobenzonitrile as model substrates. During the reaction development, we determined that Meerwein-type arylation reaction of pyridine ring was efficient in $\mathrm{CH}_{3} \mathrm{CN}$ containing $2 \mathrm{~mol} \%\left[\mathrm{Ru}(\mathrm{bpy})_{3}[\mathrm{PF} 6]_{2}\right.$ and 1.2 equivalent of tert-butyl nitrite $(\mathrm{BuONO})$ and 6.5 equivalents of $\mathrm{CF}_{3} \mathrm{CO}_{2} \mathrm{H}$ (1.6 equivalents by pyridine) under blue LEDs irradiation, affording the C2-arylated pyridine 1 in $72 \%$ isolated yield after $3 \mathrm{~h}$ (Table 1, entry 1). Other metal-based photoredox catalyst, such as $f a c-\operatorname{Ir}(\mathrm{ppy})_{3}$ or $\left(\operatorname{Ir}[\mathrm{ppy}]_{2}(\mathrm{dtbbpy})\right) \mathrm{PF}_{6}$, gave lower yield in $\mathbf{1}$, while a similar yield was observed with $\left(\operatorname{Ir}\left[\mathrm{dF}\left(\mathrm{CF}_{3}\right) \text { ppy }\right]_{2}(\mathrm{dtbpy})\right) \mathrm{PF}_{6}$. The use of eosin $\mathrm{Y}$ as organic dye afforded 1 in only $21 \%$ yield (Table 1, entries 2-5). Moreover, the arylated pyridine $\mathbf{1}$ is obtained in a low yield without photoredox catalyst (Table 1, entry 6). The presence of acid is required to obtain a good yield (Table 1, entries 7 and 8). As explained by Opatz and co-workers, DFT-calculation shows that the use of acid allows the protonation of the pyridine lowering the energy of its LUMO and facilitating the radical addition. ${ }^{17}$ A slightly larger amount of acid compared to pyridine is required owing that acid is also essential for the generation of the aryldiazonium salts from aniline and $t \mathrm{BuONO}$. The 
reaction can be performed in DMSO or water solvents, albeit in slightly lower yields (Table 1, entries 9 and 10). Control experiments showed that blue LEDs are mandatory, as 1 was not obtained when the reaction is carried out using white light or in the dark (Table 1, entries 11 and 12). As expected, no reaction occurred when the reaction is set up without tBuONO (Table 1, entry 13). Usually, a fan is used to keep the temperature at $30-35^{\circ} \mathrm{C}$. Without a fan, the temperature reached $65^{\circ} \mathrm{C}$ due to the heat released from the LEDs; but this higher temperate has no effect on the production of 1 (Table1, entry 14). A shorter reaction time (1h) gave a partial conversation, while longer reaction time $(12 \mathrm{~h})$ did not affect the chemical yield (Table 1, entries 15 and 16). The conditions reported by Carrillo's group for the $\mathrm{C}-\mathrm{H}$ bond arylation of heteroarenes and $\mathrm{N}$-oxide pyridines with L-ascorbic acid as catalyst in absence of light was inefficient with 4-cyanopyridine (Table 1 , entry 17$).{ }^{15}$

Table 1. Reaction Development and Control Experiments

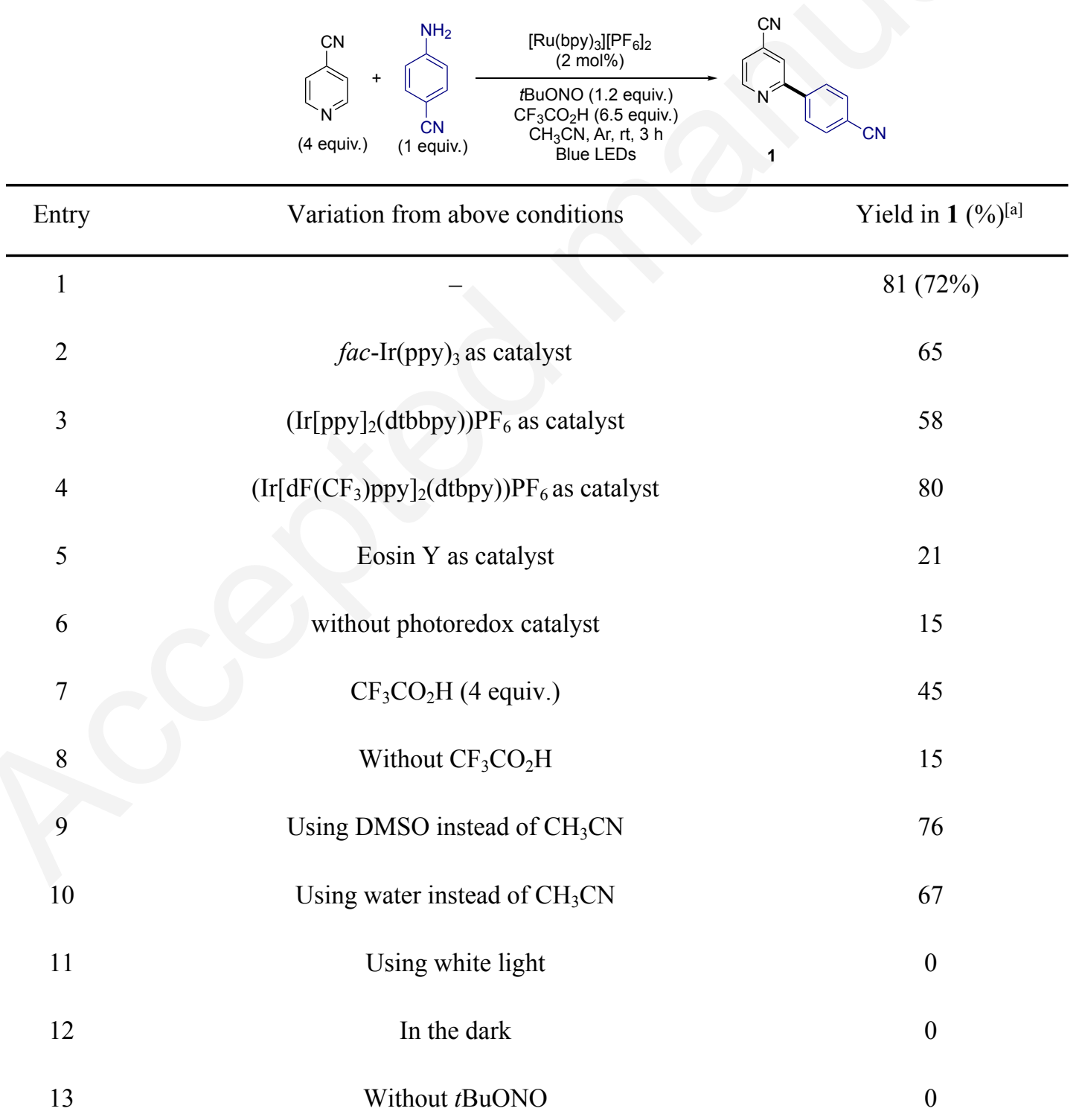


At $65^{\circ} \mathrm{C}$

$1 \mathrm{~h}$

$12 \mathrm{~h}$
78

55

82

0

[a] The yield was determined by GC-analysis using $n$-dodecane as internal standard, the isolated yield is shown in parentheses.

With the optimized conditions in hands, we turned our attention to the scope of the reaction with the respect of pyridine (Scheme 1). Firstly, we investigated a set of 4-substituted pyridines to avoid the formation of other regioisomers. ${ }^{8}$ 4-Methylpyridine, an electron-rich pyridine, exhibited a slightly lower reactivity with 4-aminobenzonitrile, affording the 2-arylated pyridine 2 in 64\% yield. Nicotinaldehyde was arylated at C2 position with 4-chloroanaline to give 3 in $78 \%$ without deformylation. Interestingly, the reaction was tolerant to $\mathrm{C}-\mathrm{Br}$ bond on the pyridine unit, as the coupling reaction between 4-bromopyridine and 4-chloroaniline afforded the $\mathrm{C} 2$-arylated pyridine 4 in $76 \%$ yield without the cleavage of both $\mathrm{C}-\mathrm{Br}$ and $\mathrm{C}-\mathrm{Cl}$ bonds providing the possibility for further diversification via $\mathrm{Pd}$-catalyzed selective cross-coupling reactions. 4-(Trifluoromethyl)pyridine and 4-acetylpyridine were also arylated at C2-position using in-situ diazotization of $p$-anisidine or 4-chloroaniline in $73 \%$ and $82 \%$ yield, respectively. Disubstituted pyridines can also be employed. From 2,4-lutidine, the C6-arylated pyridine 7 was isolated in 56\% yield as a single regioisomer. In contrast, when the reaction is carried out with 2,4-dichloropyridine, a mixture of C6 and C3 arylated pyridines $\mathbf{8 a}$ and $\mathbf{8 b}$, which can be isolated separately, are obtained in $14 \%$ and $52 \%$ yield, respectively. The formation of $\mathbf{8 b}$ as the major product might be attributed to the high electrophilic character of the carbon atom flanked by the two chlorine atoms. The arylation of 2,6-lutidine took place at $\mathrm{C} 4$ position affording 9 in $82 \%$ yield. Reaction with unsubstituted pyridine provided a mixture of $\mathrm{C} 2$ and C4 arylated products $\mathbf{1 0 a}$ and $\mathbf{1 0 b}$ with are isolated in $39 \%$ and $12 \%$ yield, respectively; but both isomers can be isolated separately by column chromatography. From 2-bromopyridine, C6 and C4 regioisomers 11a and 11b were isolated separately in 36\% and 32\% yield, respectively. We then carried out the reaction with 3-bromopyridine and we isolated the $\mathrm{C} 2$, C4 and C6 regioisomers 12a, 12b, 12c in 35\%,22\% and 15\% yield, respectively. The regioselectivities observed are similar to those observed with aryldiazonium salts, ${ }^{8-9}$ and more generally with those observed for radical addition to pyridines. ${ }^{18}$ The LUMO coefficients at C2 and C-4 of pyridine derivatives are often very similar, which explained the formation of the mixtures of regioisomers if at least one position is not blocked. ${ }^{17}$ 

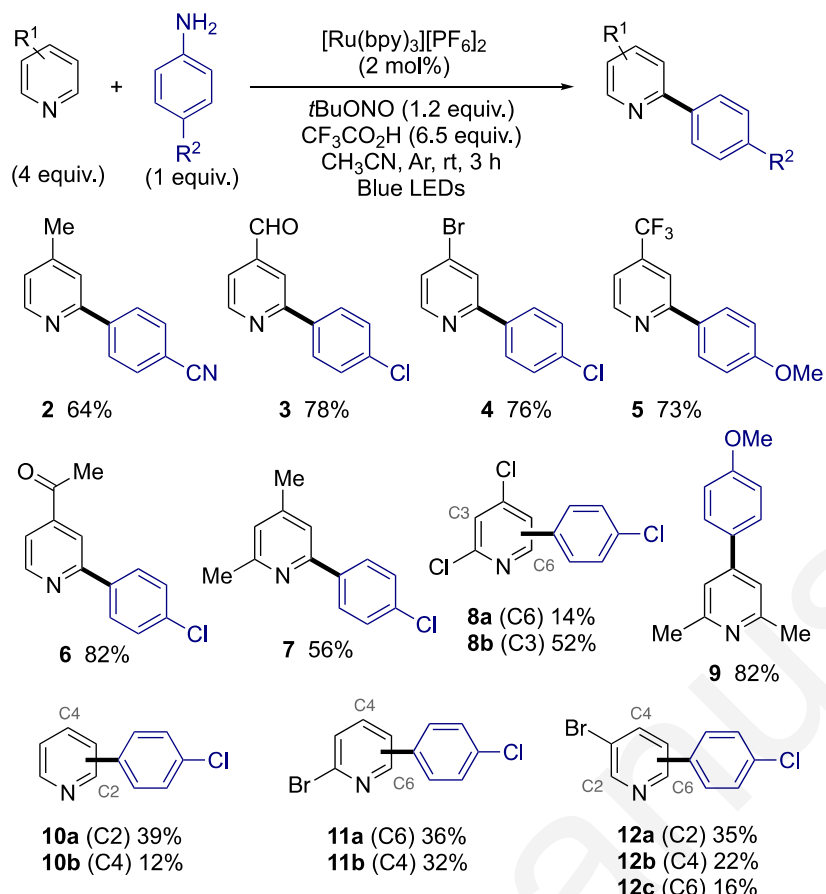

Scheme 1. Scope of Pyridine in C-H Bond Arylation with in-situ Diazotization of Anilines under Photoredox Catalysis

Next, we moved to the scope of anilines for the C2-arylation of 4-acetylpyridine under photoredox conditions (Scheme 2). From, 4-bromoaniline, the reaction was chemoselective and occurred only via diazonium coupling affording the C2-arylated pyridine 13 in $84 \%$ yield, while the $\mathrm{C}-\mathrm{Br}$ bond remains untouched. para-substituted anilines by an electron-withdrawing group (e.g., ester, acetyl, trifluoromethyl) smoothly underwent in-situ diazotizationphotoredox-triggered radical arylation to afford the C2-arylated pyridines 14-16 in 63-78\% yields. Electron-rich $p$-anisidine was efficiently coupled to give 17 in $70 \%$ yield. Metasubstituted anilines such as 3,5-difluoroanilne, 3,5-bis(trifluoromethyl)aniline, and 3-fluoro-5(trifluoromethyl)aniline were successfully employed to prepare the corresponding C2-arylated pyridines 18-20 in 45-56\% yield. The reaction is more sensitive to the presence of an orthosubstituent, as the coupling between 4-acetylpyridine and 2-fluoroaniline led to the formation of 21 in only $34 \%$ yield. 
Scheme 2. Scope of Anilines in C-H Bond Arylation of Pyridine with in-situ Diazotization of Anilines under Photoredox Catalysis

2-Arylbipyrines (precursor of CNN ligands) are generally prepared using a two-steps procedure with aryl lithium reagents under cryogenic conditions, ${ }^{19}$ via transition metal-catalyzed $\mathrm{C}-\mathrm{H}$ bond functionalization using organometallic reagents (e.g., diaryl zinc or aryl boronic acids), ${ }^{20}$ or by $\mathrm{C}-\mathrm{H}$ bond borylation of bipyridine followed by Suzuki reaction. ${ }^{21}$ To the best of our knowledge, no example of Meerwein-type arylation reaction of bipyridines is reported, yet. Although it will be a sustainable synthetic pathway to a wide variety of CNN pro-ligands, including some bearing a sensitive functional group toward organometallic reagents. Therefore, we also investigated the reactivity of 4,4'-di-tert-butyl-2,2'-bipyridine (Scheme 3). The coupling reaction between 4,4'-di-tert-butyl-2,2'-bipyridine (4 equiv.) and of 4-chloroaniline (1 equiv.) -in a mixture of $\mathrm{CH}_{3} \mathrm{CN} / \mathrm{TFA}(8: 1)$ solvent containing $2 \mathrm{~mol} \%\left[\mathrm{Ru}(\mathrm{bpy})_{3}\left[\mathrm{PF}_{6}\right]_{2}\right.$ and 1.2 equivalents of $t \mathrm{BuONO}$ under blue LEDs irradiation- afforded 22 in $24 \%$ yield. The use of 1 $\operatorname{mol} \%\left(\operatorname{Ir}\left[\mathrm{dF}\left(\mathrm{CF}_{3}\right) \mathrm{ppy}\right]_{2}(\mathrm{dtbpy})\right) \mathrm{PF}_{6}$, which displayed a lower redox potential $[\operatorname{Ir}(\mathrm{III}) / \operatorname{Ir}(\mathrm{II})=$ $1.37 \mathrm{~V}$ vs $\mathrm{Ru}(\mathrm{II}) / \mathrm{Ru}(\mathrm{I})=-1.33 \mathrm{~V}$ ] allowed the formation of 22 in $61 \%$ yield. From 4bromopyridine and 4,4'-di-tert-butyl-2,2'-bipyridine the functionalized CNN pro-ligand $\mathbf{2 3}$ is obtained in $58 \%$. Notably, this bipyridine could not be obtained using previous protocols due to the lithiation reaction. 3-Fluoro-5-(trifluoromethyl)aniline was efficiently coupled to give the 2-arylbipyridine $\mathbf{2 4}$ in $45 \%$ yield. 4,4'-Dimethyl-2,2'-bipyridine was also arylated at C2 
position using in-situ diazotization of 4-bromoaniline leading to the formation of $\mathbf{2 5}$ in $48 \%$ yield.
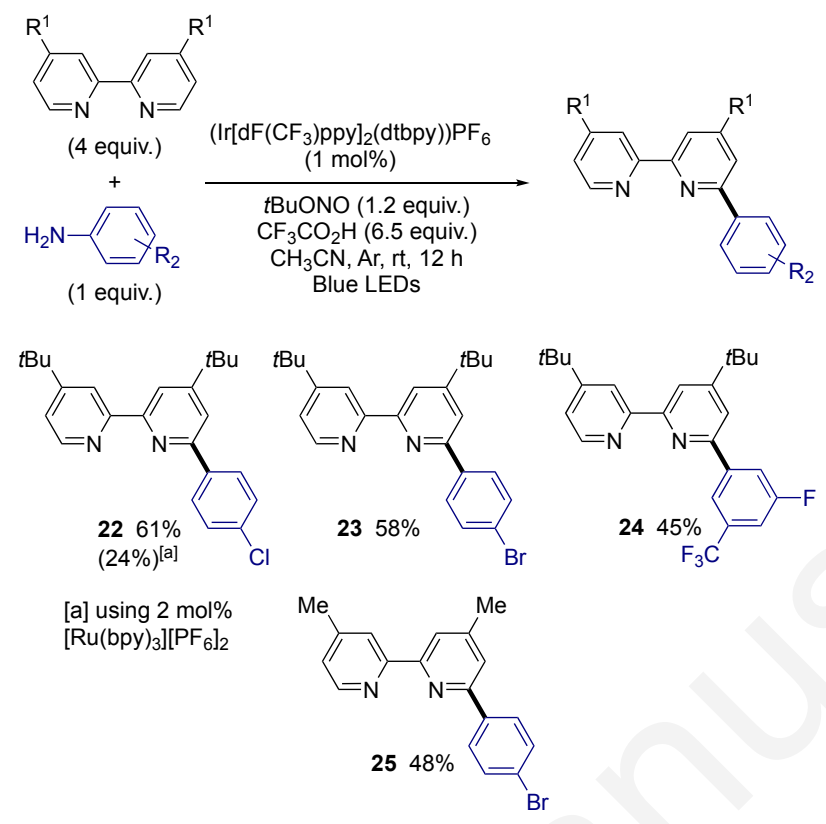

Scheme 3. Application de the Late-Stage Modification of Bipyridine Ligands

To have a better understanding of the mechanism, a radical control experiment was carried out in the presence of a radical scavenger (Figure 3a). When two equivalents of 2,2,6,6tetramethylpiperidine1-oxyl (TEMPO) was added to the reaction mixture under the standard conditions, no desired product 1 was detected. However, we have observed the formation of the 4-benzonitrile-TEMPO adduct 26 (determined by GC-MS), which arises from radical deamination of the aniline through the in-situ formation of diazonium salts. ${ }^{22}$ Also, we conducted two competitive reactions to probe the substituent preference for such couplings (Figure $3 b$ ). From an equimolar ratio of 4-cyanopyridine (4 equiv.) and 4-methylpyridine (4 equiv.) in the presence of 4-aminobenzonitrile ( 1 equiv.), we observed the formation of a mixture of 1 and $\mathbf{2}$ in a 77:23 ratio suggesting that an electron-withdrawing substituent on the pyridine ring favor the reaction. This result is in line with the aryl radical addition onto the pyridine ring. From an equimolar ratio of $p$-anisidine (1 equiv.) and ethyl 4 -aminobenzoate (1 equiv.) in the presence of 1 equivalent of tBuONO and 4-acetylpyridine (4 equiv.), we observed the formation of a mixture of $\mathbf{1 4}$ and $\mathbf{1 7}$ in a 9:91 ratio suggesting that electron-rich anilines react faster with $t$ BuONO. Moreover, KIE value of 1.1 was determined from parallel completion reactions, suggesting that the $\mathrm{C}-\mathrm{H}$ bond cleavage event is not involved in a ratedetermining step (RDS) (Figure 3c). ${ }^{23}$ 
Based on the above experimental results and literature on photoredox-catalyzed $\mathrm{C}-\mathrm{H}$ bond arylations, ${ }^{8}, 24$ a plausible mechanism is illustrated in Figure 4. Firstly, under acidic conditions aniline derivatives reacted with $t \mathrm{BuONO}$ to generate aryl diazonium salts. Upon the generation of excited state catalyst ${ }^{*} \mathrm{PC}$ from ground state of $\left[\mathrm{Ru}(\mathrm{bpy})_{3}\left[\mathrm{PF}_{6}\right]_{2}\right.$ or ( $\left.\operatorname{Ir}\left[\mathrm{dF}\left(\mathrm{CF}_{3}\right) \mathrm{ppy}\right]_{2}(\mathrm{dtbpy})\right) \mathrm{PF}_{6}$ by blue LEDs irradiation, a single electron transfer (SET) occurs from *[PC] to the aryl diazonium salts leading to the formation of a free aryl radical $\left(\mathrm{Ar}^{\bullet}\right)$ after the extrusion of dinitrogen- among with the oxidized catalyst $\left[\mathrm{PC}^{+}\right]$. Then, the aryl radical adds to the protonated pyridine at $\mathrm{C} 2$ or/and $\mathrm{C} 4$ position(s) -depending on its substitution patterns- yielding the pyridine radical-cation intermediate (A). Then, $\mathbf{A}$ is subsequently transformed into a carbocation intermediate $\mathbf{B}$ via a SET from $\left[\mathrm{Ir}^{2+}\right]$ with the loss of a proton. Finally, the rearomatization gives the desired arylated pyridine. 


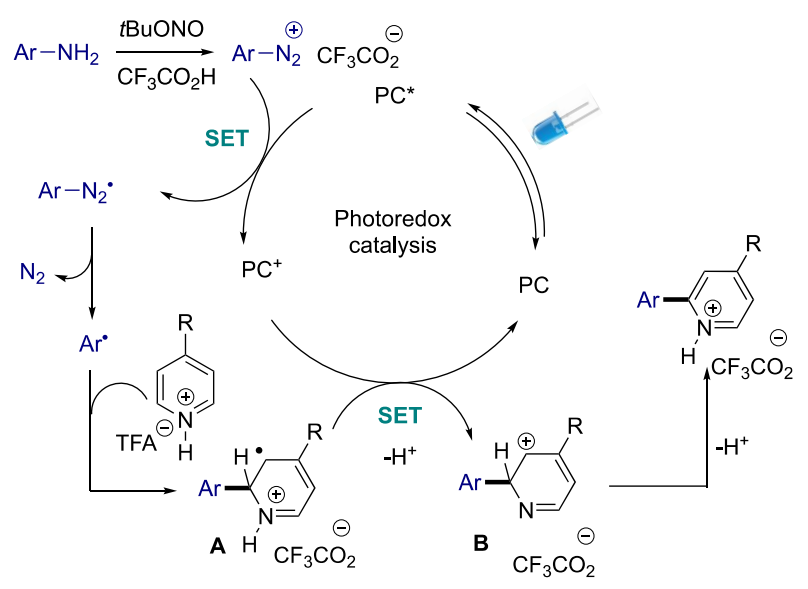

Figure 4. Proposed Mechanism

\section{Conclusion}

In summary, a highly effective visible light-promoted $\mathrm{C}-\mathrm{H}$ bond arylation of pyridines has been developed. The reaction proceeds at room temperature with $\left[\mathrm{Ru}(\mathrm{bpy})_{3}[] \mathrm{PF}_{6}\right]_{2}$ as a photosensitizer with commercially available anilines as safe aryl radical precursors via in-situ diazotization using tert-butyl nitrite. A wide variety of substituted pyridines and anilines have been efficiently coupled under these reaction conditions affording only the monoarylated products with different regioselectivities. Moreover, bipyridines have been arylated at the $\mathrm{C} 2$ position using or $\left(\operatorname{Ir}\left[\mathrm{dF}\left(\mathrm{CF}_{3}\right) \text { ppy }\right]_{2}(\mathrm{dtbpy})\right) \mathrm{PF}_{6}$ as a photosensitizer. This procedure is a practical and sustainable method for the synthesis of nitrogen ligands useful for the preparation of novel organometallics.

\section{Experimental Section}

General Remarks: All reactions were run in Schlenk tubes under argon atmosphere. Commercial pyridines and anilines were used after purification according the literature (distillation or recrystallisation). The reactions were followed by GC and NMR. 1H and 13C spectra were recorded with a Bruker $400 \mathrm{MHz}$ spectrometer in $\mathrm{CDCl}_{3}$ solutions. Chemical shifts are reported in ppm relative to $\mathrm{CDCl}_{3}$ (7.26 for $1 \mathrm{H} \mathrm{NMR}$ and 77.0 for $13 \mathrm{C} \mathrm{NMR}$ ). Flash chromatography was performed on silica gel (230-400 mesh). GC-MS analyses were performed with a GCMS-QP2010S (Shimadzu) instrument with a GC-2010 equipped with a 30 m capillary column (Supelco, SLBTM- 5ms, fused silica capillary column, $30 \mathrm{~m}$ x $0.25 \mathrm{~mm}$ x $0.25 \mathrm{~mm}$ film thickness), which was used with helium as the vector gas. The following GC conditions were used: initial temperature $80{ }^{\circ} \mathrm{C}$ for 5 minutes, then rate $20^{\circ} \mathrm{C} / \mathrm{min}$ until $280{ }^{\circ} \mathrm{C}$ and $280{ }^{\circ} \mathrm{C}$ for 28 minutes. HRMS were recorded on a Waters Q-Tof 2 mass spectrometer at 
the corresponding facilities of the CRMPO, Centre Régional de Mesures Physiques de l'Ouest, Université de Rennes 1.

General Procedure for $\mathbf{C}-\mathbf{H}$ bond arylation of pyrdines: To a $15 \mathrm{~mL}$ oven dried Schlenk tube, $\left[\mathrm{Ru}(\mathrm{bpy})_{3}\right]\left[\mathrm{PF}_{6}\right]_{2}(10.3 \mathrm{mg}, 0.012 \mathrm{mmol}, 2 \mathrm{~mol} \%)$ or $\left(\operatorname{Ir}\left[\mathrm{dF}\left(\mathrm{CF}_{3}\right) \mathrm{ppy}\right]_{2}(\mathrm{dtbpy})\right) \mathrm{PF}_{6}(6.6$ mg, $0.006 \mathrm{mmol}, 1 \mathrm{~mol} \%$ ), pyridine ( $2.4 \mathrm{mmol}, 4$ equiv.), aniline ( $0.6 \mathrm{mmol}, 1$ equiv), $\mathrm{CH}_{3} \mathrm{CN}$ $(1.2 \mathrm{~mL})$, TFA $(0.3 \mathrm{~mL})$ were successfully added under an argon atmosphere. Then, $t$ BuONO ( $88 \mu \mathrm{L}, 0.62 \mathrm{mmol}, 1.2$ equiv.) was slowly added. The Schlenk was positioned on a stir plate approximately $2-3 \mathrm{~cm}$ from two ABI PAR38 (24W) LED lamp supplying blue light $(\lambda=440$ $460 \mathrm{~nm}$ ). Fans were used for cooling. After irradiation for 3 hours, the reaction mixture was poured in a saturated aqueous solution of $\mathrm{K}_{2} \mathrm{CO}_{3}(10 \mathrm{~mL})$, and extracted several times with AcOEt $(4 \times 15 \mathrm{~mL})$. The solvent was removed under reduced pressure, and the residue was purified by flash chromatography (petroleum ether/ethyl acetate) to afford the desired product.

2-(4-Cyanophenyl)isonicotinonitrile (1): Following the general procedure using isonicotinonitrile (250 mg, $2.4 \mathrm{mmol}$ ) and 4-aminobenzonitrile ( $70 \mathrm{mg}, 0.6 \mathrm{mmol})$, the residue was purified by flash chromatography on silica gel (heptane-EtOAc, 90-10) to afford the desired compound $1(89 \mathrm{mg}, 72 \%)$ as a white solid. ${ }^{1} \mathrm{H}$ NMR (400 MHz, DMSO- $\left.d_{6}\right) \delta 8.96(\mathrm{~d}$, $J=5.0 \mathrm{~Hz}, 1 \mathrm{H}), 8.61(\mathrm{~s}, 1 \mathrm{H}), 8.34(\mathrm{~d}, J=8.4 \mathrm{~Hz}, 2 \mathrm{H}), 8.00(\mathrm{~d}, J=8.3 \mathrm{~Hz}, 2 \mathrm{H}), 7.91(\mathrm{~d}, J=$ 5.0, 1H). ${ }^{13} \mathrm{C}\left\{{ }^{1} \mathrm{H}\right\}$ NMR $\left(101 \mathrm{MHz}, \mathrm{DMSO}-d_{6}\right) \delta 155.6,151.4,141.5,133.3,128.0,125.7$, 123.6, 121.3, 119.0, 117.2, 112.9. HRMS (ESI) Calcd for: $\mathrm{C}_{13} \mathrm{H}_{8} \mathrm{~N}_{3}$ : 206.0713; Found: $206.0712[\mathrm{M}+\mathrm{H}]^{+}$.

4-(4-Methylpyridin-2-yl)benzonitrile (2): Following the general procedure using 4methylpyridine $(233 \mu \mathrm{L}, 2.4 \mathrm{mmol})$ and 4-aminobenzonitrile $(70 \mathrm{mg}, 0.6 \mathrm{mmol})$, the residue was purified by flash chromatography on silica gel (heptane-EtOAc, 95-5) to afford the desired compound 2 (75 mg, 64\%) as a white solid. ${ }^{1} \mathrm{H} \mathrm{NMR}\left(300 \mathrm{MHz}, \mathrm{CDCl}_{3}\right) \delta 8.59(\mathrm{~d}, J=5.0 \mathrm{~Hz}$, $1 \mathrm{H}), 8.12(\mathrm{~d}, J=7.8 \mathrm{~Hz}, 2 \mathrm{H}), 7.76(\mathrm{~d}, J=7.8 \mathrm{~Hz}, 2 \mathrm{H}), 7.60(\mathrm{~s}, 1 \mathrm{H}), 7.15(\mathrm{~d}, J=4.8 \mathrm{~Hz}, 1 \mathrm{H})$, $2.46(\mathrm{~s}, 3 \mathrm{H}) .{ }^{13} \mathrm{C}\left\{{ }^{1} \mathrm{H}\right\} \quad \mathrm{NMR}\left(75 \mathrm{MHz}, \mathrm{CDCl}_{3}\right) \delta 154.8,149.7,148.0,143.7,132.6,127.3$, $124.2,121.7,118.8,111.9,21.2$. The NMR data are identical to those reported in the literature. ${ }^{25}$

2-(4-Chlorophenyl)isonicotinaldehyde (3): Following the general procedure using isonicotinaldehyde $(210 \mu \mathrm{L}, 2.4 \mathrm{mmol})$ and 4-chloroaniline (76 mg, $0.6 \mathrm{mmol})$, the residue was purified by flash chromatography on silica gel (heptane-EtOAc, 95-5) to afford the desired compound 3 (101 mg, 78\%) as a white solid. ${ }^{1} \mathrm{H}$ NMR (400 MHz, $\left.\mathrm{CDCl}_{3}\right) \delta 10.16(\mathrm{~s}, 1 \mathrm{H}), 8.96$ 
$(\mathrm{d}, J=4.9 \mathrm{~Hz}, 1 \mathrm{H}), 8.12(\mathrm{~s}, 1 \mathrm{H}), 8.04(\mathrm{~d}, J=7.8 \mathrm{~Hz}, 2 \mathrm{H}), 7.67(\mathrm{~d}, J=4.9,1 \mathrm{H}), 7.50$ (d, $J=7.9$ $\mathrm{Hz}, 2 \mathrm{H}) .{ }^{13} \mathrm{C}\left\{{ }^{1} \mathrm{H}\right\} \quad \mathrm{NMR}\left(101 \mathrm{MHz}, \mathrm{CDCl}_{3}\right) \delta 191.4,157.8,151.1,142.5,136.6,135.9,129.1$, 128.2, 120.9, 118.4. HRMS (ESI) Calcd for: $\mathrm{C}_{12} \mathrm{H}_{9} \mathrm{NO}^{35} \mathrm{Cl}$ : 218.0367; Found: 218.0367 $[\mathrm{M}+\mathrm{H}]^{+}$.

4-bromo-2-(4-chlorophenyl)pyridine (4): Following the general procedure using 4bromopyridine (466 mg, $2.4 \mathrm{mmol}$ ) and 4-chloroaniline (76 $\mathrm{mg}, 0.6 \mathrm{mmol}$ ), the residue was purified by flash chromatography on silica gel (heptane-EtOAc, 99-1) to afford the desired compound $4(122 \mathrm{mg}, 76 \%)$ as a yellow solid. ${ }^{1} \mathrm{H}$ NMR $\left(400 \mathrm{MHz}, \mathrm{CDCl}_{3}\right) \delta 8.51(\mathrm{~d}, J=5.2$ $\mathrm{Hz}, 1 \mathrm{H}), 7.94(\mathrm{~d}, J=8.6 \mathrm{~Hz}, 2 \mathrm{H}), 7.89(\mathrm{~s}, 1 \mathrm{H}), 7.47(\mathrm{~d}, J=8.4,2 \mathrm{H}), 7.43(\mathrm{~d}, J=6.6 \mathrm{~Hz}, 1 \mathrm{H})$. ${ }^{13} \mathrm{C}\left\{{ }^{1} \mathrm{H}\right\} \quad \mathrm{NMR}\left(101 \mathrm{MHz}, \mathrm{CDCl}_{3}\right) \delta 157.6,150.4,136.4,135.8,133.6,129.0,128.2,125.5$, 123.6. HRMS (ESI) Calcd for: $\mathrm{C}_{11} \mathrm{H}_{8} \mathrm{~N}^{35} \mathrm{Cl}^{79} \mathrm{Br}$ : 267.9523; Found: $267.9526[\mathrm{M}+\mathrm{H}]^{+}$.

2-(4-methoxyphenyl)-4-(trifluoromethyl)pyridine (5): Following the general procedure using 4-(trifluoromethyl)pyridine ( $257 \mu \mathrm{L}, 2.4 \mathrm{mmol})$ and 4-methoxyaniline (74 mg, $0.6 \mathrm{mmol})$, the residue was purified by flash chromatography on silica gel (heptane-EtOAc, 96-4) to afford the desired compound $5(113 \mathrm{mg}, 73 \%)$ as a yellow solid. ${ }^{1} \mathrm{H} \mathrm{NMR}\left(400 \mathrm{MHz}, \mathrm{CDCl}_{3}\right) \delta 8.83$ $(\mathrm{d}, J=5.0 \mathrm{~Hz}, 1 \mathrm{H}), 8.02(\mathrm{~d}, J=8.9 \mathrm{~Hz}, 2 \mathrm{H}), 7.88(\mathrm{~s}, 1 \mathrm{H}), 7.40(\mathrm{~d}, J=5.7 \mathrm{~Hz}, 1 \mathrm{H}), 7.04(\mathrm{~d}, J$ $=8.9 \mathrm{~Hz}, 2 \mathrm{H}), 3.90(\mathrm{~s}, 3 \mathrm{H}) \cdot{ }^{13} \mathrm{C}\left\{{ }^{1} \mathrm{H}\right\} \quad \mathrm{NMR}\left(101 \mathrm{MHz}, \mathrm{CDCl}_{3}\right) \delta 161.1,158.3,150.4,139.0$ $(\mathrm{q}, J=33.7 \mathrm{~Hz}), 130.6,128.3,123.0(\mathrm{q}, J=273.2 \mathrm{~Hz}), 116.7(\mathrm{q}, J=3.4 \mathrm{~Hz}), 115.1$ (q, $J=3.6$ $\mathrm{Hz}), 114.3,55.3$. The NMR data are identical to those reported in the literature. ${ }^{8}$

1-(2-(4-chlorophenyl)pyridin-4-yl)ethan-1-one (6): Following the general procedure using 4acetylpyridine $(264 \mu \mathrm{L}, 2.4 \mathrm{mmol})$ and 4-chloroaniline $(76 \mathrm{mg}, 0.6 \mathrm{mmol})$, the residue was purified by flash chromatography on silica gel (heptane-EtOAc, 95-5) to afford the desired compound $6(114 \mathrm{mg}, 86 \%)$ as a yellow solid. ${ }^{1} \mathrm{H}$ NMR $\left(400 \mathrm{MHz}, \mathrm{CDCl}_{3}\right) \delta 8.86(\mathrm{~d}, J=5.0$ $\mathrm{Hz}, 1 \mathrm{H}), 8.13(\mathrm{~s}, 1 \mathrm{H}), 8.00$ (d, $J=8.6 \mathrm{~Hz}, 2 \mathrm{H}), 7.66(\mathrm{~d}, J=6.4 \mathrm{~Hz}, 1 \mathrm{H}), 7.46(\mathrm{~d}, J=8.6 \mathrm{~Hz}$, 2H), $2.68(\mathrm{~s}, 3 \mathrm{H}) .{ }^{13} \mathrm{C}\left\{{ }^{1} \mathrm{H}\right\} \quad \mathrm{NMR}\left(101 \mathrm{MHz}, \mathrm{CDCl}_{3}\right) \delta 197.2,157.5,150.8,143.8,136.9$, $135.7,129.0,128.2,120.0,117.6,26.7$. The NMR data are identical to those reported in the literature..$^{26}$

2-(4-Methoxyphenyl)-4,6-dimethylpyridine (7): Following the general procedure using 2,4lutidine $(277 \mu \mathrm{L}, 2.4 \mathrm{mmol})$ and 4-methoxyaniline $(74 \mathrm{mg}, 0.6 \mathrm{mmol})$, the residue was purified by flash chromatography on silica gel (heptane-EtOAc, 95-5) to afford the desired compound $7(73 \mathrm{mg}, 56 \%)$ as a yellow solid. ${ }^{1} \mathrm{H}$ NMR $\left(300 \mathrm{MHz}, \mathrm{CDCl}_{3}\right) \delta 7.94(\mathrm{~d}, J=8.6 \mathrm{~Hz}, 1 \mathrm{H}), 7.30$ 
$(\mathrm{s}, 1 \mathrm{H}), 6.99(\mathrm{~d}, J=8.6 \mathrm{~Hz}, 1 \mathrm{H}), 6.90(\mathrm{~s}, 1 \mathrm{H}), 3.87(\mathrm{~s}, 3 \mathrm{H}), 2.58(\mathrm{~s}, 3 \mathrm{H}), 2.37(\mathrm{~s}, 3 \mathrm{H}) .{ }^{13} \mathrm{C}\left\{{ }^{1} \mathrm{H}\right\}$ NMR $\left(75 \mathrm{MHz}, \mathrm{CDCl}_{3}\right) \delta 160.1,157.9,156.5,147.6,132.5,128.2,121.9,117.9,113.9,55.3$, 24.5, 21.0. The NMR data are identical to those reported in the literature ${ }^{8}$

\section{2,4-dichloro-6-(4-methoxyphenyl)pyridine (8a) and 2,4-dichloro-3-(4-} methoxyphenyl)pyridine (8b): Following the general procedure using 2,4-dichloropyridine (354 mg, $2.4 \mathrm{mmol}$ ) and 4-methoxyaniline (74 mg, $0.6 \mathrm{mmol})$, the residue was purified by flash chromatography on silica gel (heptane-EtOAc, 98-2) to afford the desired compounds 8a (22 $\mathrm{mg}, 14 \%)$ as a white solid and $\mathbf{8 b}(81 \mathrm{mg}, 52 \%)$ as a white solid. 8a ${ }^{1} \mathrm{H}$ NMR (400 MHz, $\left.\mathrm{CDCl}_{3}\right) \delta 8.34(\mathrm{~s}, 1 \mathrm{H}), 7.49(\mathrm{~s}, 1 \mathrm{H}), 7.39(\mathrm{~d}, J=8.8 \mathrm{~Hz}, 2 \mathrm{H}), 7.03(\mathrm{~d}, J=8.8 \mathrm{~Hz}, 2 \mathrm{H}), 3.89$ (s, $3 \mathrm{H}) .{ }^{13} \mathrm{C} \mathrm{NMR}\left(101 \mathrm{MHz}, \mathrm{CDCl}_{3}\right) \delta 160.0,150.6,150.1,144.1,135.1,130.7,126.5,124.7$, 114.0, 55.4. 8b ${ }^{1} \mathrm{H}$ NMR $\left(300 \mathrm{MHz}, \mathrm{CDCl}_{3}\right) \delta 8.28(\mathrm{~d}, J=5.3 \mathrm{~Hz}, 1 \mathrm{H}), 7.40(\mathrm{~d}, J=5.3 \mathrm{~Hz}$, 1H), $7.24(\mathrm{~d}, J=8.7 \mathrm{~Hz}, 2 \mathrm{H}), 7.03(\mathrm{~d}, J=8.7 \mathrm{~Hz}, 2 \mathrm{H}), 3.89(\mathrm{~s}, 3 \mathrm{H}) .{ }^{13} \mathrm{C}\left\{{ }^{1} \mathrm{H}\right\}$ NMR $(75 \mathrm{MHz}$, $\left.\mathrm{CDCl}_{3}\right) \delta 159.8,152.3,148.1,145.7,135.7,130.6,126.9,123.8,113.9,55.2$. HRMS (ESI) Calcd for: $\mathrm{C}_{12} \mathrm{H}_{9} \mathrm{NO}^{35} \mathrm{Cl}_{2} \mathrm{Na}$ : 275.9953; Found: $275.9953[\mathrm{M}+\mathrm{Na}]^{+}$.

4-(4-Methoxyphenyl)-2,6-dimethylpyridine (9): Following the general procedure using 2,6lutidine $(277 \mu \mathrm{L}, 2.4 \mathrm{mmol})$ and 4-methoxyaniline $(74 \mathrm{mg}, 0.6 \mathrm{mmol})$, the residue was purified by flash chromatography on silica gel (heptane-EtOAc, 80-20) to afford the desired compound 9 (105 mg, 82\%) as a yellow solid. ${ }^{1} \mathrm{H}$ NMR (400 MHz, $\left.\mathrm{CDCl}_{3}\right) \delta 7.59(\mathrm{~d}, J=8.8 \mathrm{~Hz}, 2 \mathrm{H})$, $7.17(\mathrm{~s}, 2 \mathrm{H}), 7.01(\mathrm{~d}, J=8.8 \mathrm{~Hz}, 2 \mathrm{H}), 3.88(\mathrm{~s}, 3 \mathrm{H}), 2.59(\mathrm{~s}, 6 \mathrm{H}) \cdot{ }^{13} \mathrm{C}\left\{{ }^{1} \mathrm{H}\right\}$ NMR $(101 \mathrm{MHz}$, $\left.\mathrm{CDCl}_{3}\right) \delta 160.3,158.0,148.5,130.9,128.1,117.8,114.3,55.3,24.5$. HRMS (ESI) Calcd for: $\mathrm{C}_{14} \mathrm{H}_{16} \mathrm{NO}$ : 214.1226; Found: $214.1226[\mathrm{M}+\mathrm{H}]^{+}$.

2-(4-methoxyphenyl)pyridine (10a) and 4-(4-methoxyphenyl)pyridine (10b): Following the general procedure using pyridine $(193 \mu \mathrm{L}, 2.4 \mathrm{mmol})$ and 4-methoxyaniline (74 $\mathrm{mg}, 0.6$ $\mathrm{mmol}$ ), the residue was purified by flash chromatography on silica gel (heptane-EtOAc, 70-30) to afford the desired compounds 10a (43 $\mathrm{mg}, 39 \%)$ as a white solid and $\mathbf{8 b}$ (13 $\mathrm{mg}, 12 \%)$ as a white solid. 10a ${ }^{1} \mathrm{H}$ NMR (400 MHz, $\left.\mathrm{CDCl}_{3}\right) \delta 8.68(\mathrm{~d}, J=4.7 \mathrm{~Hz}, 1 \mathrm{H}), 7.98(\mathrm{~d}, J=8.9 \mathrm{~Hz}$, 2H), 7.76-7.66 (m, 2H), $7.20(\mathrm{~m}, 1 \mathrm{H}), 7.02(\mathrm{~d}, J=8.9 \mathrm{~Hz}, 2 \mathrm{H}), 3.89$ (s, 3H). 10b ${ }^{1} \mathrm{H}$ NMR (400 $\left.\mathrm{MHz}, \mathrm{CDCl}_{3}\right) \delta 8.64(\mathrm{~d}, J=4.0 \mathrm{~Hz}, 1 \mathrm{H}), 7.63(\mathrm{~d}, J=8.9 \mathrm{~Hz}, 1 \mathrm{H}), 7.50(\mathrm{~d}, J=6.0 \mathrm{~Hz}, 1 \mathrm{H})$, $7.04(\mathrm{~d}, J=8.8 \mathrm{~Hz}, 1 \mathrm{H}), 3.90(\mathrm{~s}, 1 \mathrm{H})$. The NMR data are identical to those reported in the literature. ${ }^{8}$ 


\section{2-Bromo-6-(4-chlorophenyl)pyridine (11a) and 2-bromo-4-(4-chlorophenyl)pyridine}

(11b): Following the general procedure using 2-bromopyridine $(229 \mu \mathrm{L}, 2.4 \mathrm{mmol})$ and 4chloroaniline (76 $\mathrm{mg}, 0.6 \mathrm{mmol}$ ), the residue was purified by flash chromatography on silica gel (heptane-EtOAc, 70-30) to afford the desired compounds11a (58 mg, 36\%) as a white solid and 11b (51 mg, 32\%) as a white solid. 11a ${ }^{1} \mathrm{H}$ NMR (400 MHz, $\left.\mathrm{CDCl}_{3}\right) \delta 7.96(\mathrm{~d}, J=8.5 \mathrm{~Hz}$, 2H), $7.68(\mathrm{~d}, J=7.6 \mathrm{~Hz}, 1 \mathrm{H}), 7.62(\mathrm{t}, J=7.7 \mathrm{~Hz}, 1 \mathrm{H}), 7.48-7.42(\mathrm{~m}, 3 \mathrm{H}) .{ }^{13} \mathrm{C} \mathrm{NMR}(400$ $\left.\mathrm{MHz}, \mathrm{CDCl}_{3}\right) \delta 157.3,142.2,139.1,136.0,135.9,129.0,128.2,126.6,118.8$. The NMR data are identical to those reported in the literature. ${ }^{27} \mathbf{1 1 b}{ }^{1} \mathrm{H}$ NMR $\left(400 \mathrm{MHz}, \mathrm{CDCl}_{3}\right) \delta 8.44(\mathrm{~d}, J$ $=5.1 \mathrm{~Hz}, 1 \mathrm{H}), 7.70(\mathrm{~s}, 1 \mathrm{H}), 7.57(\mathrm{~d}, J=8.5 \mathrm{~Hz}, 2 \mathrm{H}), 7.50(\mathrm{~d}, J=8.6 \mathrm{~Hz}, 2 \mathrm{H}), 7.45(\mathrm{~d}, J=5.1$ $\mathrm{Hz}, 1 \mathrm{H}) .{ }^{13} \mathrm{C} \mathrm{NMR}\left(400 \mathrm{MHz}, \mathrm{CDCl}_{3}\right) \delta 150.5,150.0,143.1,136.1,135.1,129.5,128.3,125.7$, 120.6. The NMR data are identical to those reported in the literature. ${ }^{28}$

\section{3-Bromo-2-(4-chlorophenyl)pyridine (12a), 3-bromo-4-(4-chlorophenyl)pyridine and 5-} bromo-2-(4-chlorophenyl)pyridine (12c): Following the general procedure using 3bromopyridine $(231 \mu \mathrm{L}, 2.4 \mathrm{mmol})$ and 4-chloroaniline $(76 \mathrm{mg}, 0.6 \mathrm{mmol})$, the residue was purified by flash chromatography on silica gel (heptane-EtOAc, 70-30) to afford the desired compounds 12a (56 mg, 35\%) as a white solid, $\mathbf{1 2 b}$ (35 mg, 22\%) as a white solid and $\mathbf{1 2 c}$ (26 mg, 16\%) as a white solid. 12a ${ }^{1} \mathrm{H}$ NMR $\left(400 \mathrm{MHz} \mathrm{CDCl}_{3}\right) \delta 8.74(\mathrm{~d}, J=2.4 \mathrm{~Hz}, 1 \mathrm{H}), 7.93(\mathrm{~d}$, $J=8.6 \mathrm{~Hz}, 2 \mathrm{H}), 7.89(\mathrm{dd}, J=2.4,8.5 \mathrm{~Hz}, 1 \mathrm{H}), 7.61$ (d, $J=8.5 \mathrm{~Hz}, 1 \mathrm{H}), 7.46(\mathrm{~d}, J=8.4 \mathrm{~Hz}$, 2H). ${ }^{13} \mathrm{C} \mathrm{NMR}\left(400 \mathrm{MHz}, \mathrm{CDCl}_{3}\right) \delta 154.6,150.8,139.4,136.6,135.5,129.1,128.0,121.4$, 119.6. The NMR data are identical to those reported in the literature. ${ }^{29} \mathbf{1 2 b}{ }^{1} \mathrm{H}$ NMR (400 $\left.\mathrm{MHz}, \mathrm{CDCl}_{3}\right) \delta 8.89-8.80(\mathrm{~m}, 1 \mathrm{H}), 8.62-8.53(\mathrm{~m}, 1 \mathrm{H}), 7.48(\mathrm{~d}, J=8.4 \mathrm{~Hz}, 2 \mathrm{H}), 7.40(\mathrm{~d}, J=$ $8.4 \mathrm{~Hz}, 2 \mathrm{H}), 7.31-7.24(\mathrm{~m}, 1 \mathrm{H}) .{ }^{13} \mathrm{C} \mathrm{NMR}\left(400 \mathrm{MHz}, \mathrm{CDCl}_{3}\right) \delta 152.6,148.5,148.4,136.5$, 135.1, 130.8, 130.2, 128.7, 128.2, 125.4. HRMS (ESI) Calcd for: $\mathrm{C}_{11} \mathrm{H}_{8} \mathrm{~N}^{35} \mathrm{Cl}^{79} \mathrm{Br}$ : 267.9524; Found: $267.9526[\mathrm{M}+\mathrm{H}]^{+}$. 12c ${ }^{1} \mathrm{H} \mathrm{NMR}\left(400 \mathrm{MHz}, \mathrm{CDCl}_{3}\right) \delta 8.64(\mathrm{dd}, J=1.5,4.7 \mathrm{~Hz}, 1 \mathrm{H})$, $8.01(\mathrm{dd}, J=1.5,8.1 \mathrm{~Hz}, 1 \mathrm{H}), 7.72-7.61(\mathrm{~m}, 2 \mathrm{H}), 7.46$ (d, $J=8.6 \mathrm{~Hz}, 2 \mathrm{H}), 7.17$ (dd, $J=4.6$, $8.1 \mathrm{~Hz}, 1 \mathrm{H}) .{ }^{13} \mathrm{C}$ NMR $\left(400 \mathrm{MHz}, \mathrm{CDCl}_{3}\right) \delta 157.0,148.2,141.4,137.9,134.9,130.8,128.2$, 127.0, 123.5, 119.7. HRMS (ESI) Calcd for: $\mathrm{C}_{11} \mathrm{H}_{8} \mathrm{~N}^{35} \mathrm{Cl}^{79} \mathrm{Br}$ : 267.9526; Found: 267.9526 $[\mathrm{M}+\mathrm{H}]^{+}$.

1-(2-(4-Bromophenyl)pyridin-4-yl)ethan-1-one (13): Following the general procedure using 4-acetylpyridine (264 $\mu \mathrm{L}, 2.4 \mathrm{mmol})$ and 4-bromoaniline (103 $\mathrm{mg}, 0.6 \mathrm{mmol})$, the residue was purified by flash chromatography on silica gel (heptane-EtOAc, 95-5) to afford the desired compound $13(139 \mathrm{mg}, 84 \%)$ as a yellow solid. ${ }^{1} \mathrm{H} \mathrm{NMR}\left(400 \mathrm{MHz}, \mathrm{CDCl}_{3}\right) \delta 8.86(\mathrm{~d}, J=5.0$ $\mathrm{Hz}, 1 \mathrm{H}), 8.14$ (s, 1H), 7.94 (d, $J=8.6 \mathrm{~Hz}, 2 \mathrm{H}), 7.67$ (d, $J=5.0 \mathrm{~Hz}, 1 \mathrm{H}), 7.63$ (d, $J=8.6 \mathrm{~Hz}$, 
2H), $2.68(\mathrm{~s}, 3 \mathrm{H}) .{ }^{13} \mathrm{C}\left\{{ }^{1} \mathrm{H}\right\} \operatorname{NMR}\left(101 \mathrm{MHz}, \mathrm{CDCl}_{3}\right) \delta 197.2,157.5,150.9,143.8,137.4,132.0$, $128.5,124.1,120.0,117.5,26.7$. The NMR data are identical to those reported in the literature. ${ }^{26}$

Ethyl 4-(4-acetylpyridin-2-yl)benzoate (14): Following the general procedure using 4acetylpyridine ( $264 \mu \mathrm{L}, 2.4 \mathrm{mmol}$ ) and ethyl 4-aminobenzoate (99 $\mathrm{mg}, 0.6 \mathrm{mmol}$ ), the residue was purified by flash chromatography on silica gel (heptane-EtOAc, 80-20) to afford the desired compound 14 (126 mg, 18\%) as a white solid. ${ }^{1} \mathrm{H}$ NMR (400 MHz, $\left.\mathrm{CDCl}_{3}\right) \delta 8.89(\mathrm{~d}$, $J=5.0 \mathrm{~Hz}, 1 \mathrm{H}), 8.20(\mathrm{~s}, 1 \mathrm{H}), 8.16(\mathrm{~d}, J=8.5 \mathrm{~Hz}, 2 \mathrm{H}), 8.11(\mathrm{~d}, J=8.5 \mathrm{~Hz}, 2 \mathrm{H}), 7.69$ (d, $J=5.0$ $\mathrm{Hz}, 1 \mathrm{H}), 4.41(\mathrm{q}, J=7.1 \mathrm{~Hz}, 2 \mathrm{H}), 2.68(\mathrm{~s}, 3 \mathrm{H}), 1.42(\mathrm{t}, J=7.1 \mathrm{~Hz}, 3 \mathrm{H}) .{ }^{13} \mathrm{C}\left\{{ }^{1} \mathrm{H}\right\}$ NMR $(101$ $\left.\mathrm{MHz}, \mathrm{CDCl}_{3}\right) \delta 197.1,166.2,157.5,150.9,143.8,142.4,131.2,130.0,126.8,120.4,118.2$, 61.1, 26.7, 14.3. HRMS (ESI) Calcd for: $\mathrm{C}_{16} \mathrm{H}_{15} \mathrm{NO}_{3} \mathrm{Na}$ : 292.0944; Found: 292.0944 [M+Na] $]^{+}$

1-(2-(4-Acetylphenyl)pyridin-4-yl)ethan-1-one (15): Following the general procedure using 4-acetylpyridine ( $264 \mu \mathrm{L}, 2.4 \mathrm{mmol})$ and 4'-aminoacetophenone ( $81 \mathrm{mg}, 0.6 \mathrm{mmol})$, the residue was purified by flash chromatography on silica gel (heptane-EtOAc, 90-10) to afford the desired compound 15 (102 mg, 71\%) as a white solid. ${ }^{1} \mathrm{H}$ NMR (400 MHz, $\left.\mathrm{CDCl}_{3}\right) \delta 8.94(\mathrm{~d}$, $J=4.9 \mathrm{~Hz}, 1 \mathrm{H}), 8.25(\mathrm{~s}, 1 \mathrm{H}), 8.19(\mathrm{~d}, J=8.5 \mathrm{~Hz}, 2 \mathrm{H}), 8.11$ (d, $J=8.5 \mathrm{~Hz}, 2 \mathrm{H}), 7.73(\mathrm{~d}, J=5.0$ $\mathrm{Hz}, 1 \mathrm{H}), 2.72$ (s, 3H), 2.69 (s, 3H). ${ }^{13} \mathrm{C}\left\{{ }^{1} \mathrm{H}\right\} \mathrm{NMR}\left(101 \mathrm{MHz}, \mathrm{CDCl}_{3}\right) \delta 197.7,197.1,157.4$, 151.0, 143.8, 142.7, 137.6, 128.9, 127.1, 120.5, 118.3, 77.3, 26.7. HRMS (ESI) Calcd for: $\mathrm{C}_{15} \mathrm{H}_{13} \mathrm{NO}_{2} \mathrm{Na}$ : 262.0839; Found: $262.0840[\mathrm{M}+\mathrm{Na}]^{+}$.

1-(2-(4-(Trifluoromethyl)phenyl)pyridin-4-yl)ethan-1-one (16): Following the general procedure using 4-acetylpyridine $(264 \mu \mathrm{L}, 2.4 \mathrm{mmol})$ and 4-(trifluoromethyl)aniline $(96 \mathrm{mg}$, $0.6 \mathrm{mmol}$ ), the residue was purified by flash chromatography on silica gel (heptane-EtOAc, 964) to afford the desired compound $16(100 \mathrm{mg}, 63 \%)$ as a yellow solid. ${ }^{1} \mathrm{H}$ NMR $(400 \mathrm{MHz}$, $\left.\mathrm{CDCl}_{3}\right) \delta 8.94(\mathrm{~d}, J=5.0 \mathrm{~Hz}, 1 \mathrm{H}), 8.23(\mathrm{~s}, 1 \mathrm{H}), 8.20(\mathrm{~d}, J=8.1 \mathrm{~Hz}, 2 \mathrm{H}), 7.78(\mathrm{~d}, J=8.2 \mathrm{~Hz}$, $2 \mathrm{H}), 7.74(\mathrm{~d}, J=5.0 \mathrm{~Hz}, 1 \mathrm{H}), 2.72(\mathrm{~s}, 3 \mathrm{H}) .{ }^{13} \mathrm{C}\left\{{ }^{1} \mathrm{H}\right\} \quad \mathrm{NMR}\left(101 \mathrm{MHz}, \mathrm{CDCl}_{3}\right) \delta 197.1,157.2$, $151.1,143.9,141.8,131.3(\mathrm{q}, J=32.5 \mathrm{~Hz}), 127.3,125.8(\mathrm{q}, J=3.8 \mathrm{~Hz}), 120.7,124.1$ (q, $J=$ 272.2 Hz), 118.2, 26.8. HRMS (ESI) Calcd for: $\mathrm{C}_{14} \mathrm{H}_{10} \mathrm{NOF}_{3} \mathrm{Na}$ : 288.0607; Found: 288.0607 $[\mathrm{M}+\mathrm{Na}]^{+}$.

1-(2-(4-Methoxyphenyl)pyridin-4-yl)ethan-1-one (17): Following the general procedure using 4-acetylpyridine (264 $\mu \mathrm{L}, 2.4 \mathrm{mmol})$ and 4-methoxyaniline (74 $\mathrm{mg}, 0.6 \mathrm{mmol})$, the residue was purified by flash chromatography on silica gel (heptane-EtOAc, 85-15) to afford the desired compound 17 (95 mg, 70\%) as a yellow solid. $\left.{ }^{1} \mathrm{H} \mathrm{NMR} \mathrm{(400} \mathrm{MHz,} \mathrm{CDCl}_{3}\right) \delta 8.83$ 
$(\mathrm{d}, J=5.0 \mathrm{~Hz}, 1 \mathrm{H}), 8.12(\mathrm{~s}, 1 \mathrm{H}), 8.03(\mathrm{~d}, J=8.9 \mathrm{~Hz}, 2 \mathrm{H}), 7.60(\mathrm{~d}, J=5.0 \mathrm{~Hz}, 1 \mathrm{H}), 7.03(\mathrm{~d}, J$ $=8.9 \mathrm{~Hz}, 2 \mathrm{H}), 3.89(\mathrm{~s}, 3 \mathrm{H}), 2.68(\mathrm{~s}, 3 \mathrm{H}) .{ }^{13} \mathrm{C}\left\{{ }^{1} \mathrm{H}\right\} \quad \mathrm{NMR}\left(101 \mathrm{MHz}, \mathrm{CDCl}_{3}\right) \delta$ 197.6, 160.9, 158.4, 150.6, 143.6, 131.1, 128.3, 118.9, 117.1, 114.2, 55.3, 26.7. The NMR data are identical to those reported in the literature. ${ }^{26}$

1-(2-(3,5-difluorophenyl)pyridin-4-yl)ethan-1-one (18): Following the general procedure using 4-acetylpyridine (264 $\mu \mathrm{L}, 2.4 \mathrm{mmol})$ and 3,5-difluoroaniline (77 $\mathrm{mg}, 0.6 \mathrm{mmol})$, the residue was purified by flash chromatography on silica gel (heptane-EtOAc, 96-4) to afford the desired compound 18 (78 mg, 56\%) as a yellow solid. ${ }^{1} \mathrm{H}$ NMR (400 MHz, $\left.\mathrm{CDCl}_{3}\right) \delta 8.89(\mathrm{~d}$, $J=5.0 \mathrm{~Hz}, 1 \mathrm{H}), 8.14(\mathrm{~s}, 1 \mathrm{H}), 7.73(\mathrm{~d}, J=5.0,1 \mathrm{H}), 7.64-7.60(\mathrm{~m}, 2 \mathrm{H}), 6.91(\mathrm{tt}, J=8.6,2.3$ $\mathrm{Hz}, 1 \mathrm{H}), 2.71(\mathrm{~s}, 3 \mathrm{H}) .{ }^{13} \mathrm{C}\left\{{ }^{1} \mathrm{H}\right\} \quad \mathrm{NMR}\left(101 \mathrm{MHz}, \mathrm{CDCl}_{3}\right) \delta 196.9,163.5(\mathrm{dd}, J=248.4,12.7$ Hz), 156.1, 150.9, 143.9, 141.8 (t, $J=9.3 \mathrm{~Hz}), 120.8,117.8,109.9$ (d, $J=26.6 \mathrm{~Hz}), 104.7$ (t, $J$ $=25.4 \mathrm{~Hz}$ ), 26.7. HRMS (ESI) Calcd for: $\mathrm{C}_{13} \mathrm{H}_{9} \mathrm{NOF}_{2} \mathrm{Na}$ : 256.0544; Found: $256.0545[\mathrm{M}+\mathrm{Na}]^{+}$.

1-(2-(3,5-bBs(trifluoromethyl)phenyl)pyridin-4-yl)ethan-1-one (19): Following the general procedure using 4-acetylpyridine $(264 \mu \mathrm{L}, 2.4 \mathrm{mmol})$ and 3,5-bis(trifluoromethyl)aniline (93 $\mu \mathrm{L}, 0.6 \mathrm{mmol}$ ), the residue was purified by flash chromatography on silica gel (heptane-EtOAc, 96-4) to afford the desired compound 19 (104 mg, 52\%) as a yellow solid. ${ }^{1} \mathrm{H}$ NMR (400 MHz, $\left.\mathrm{CDCl}_{3}\right) \delta 8.97(\mathrm{~d}, J=5.0 \mathrm{~Hz}, 1 \mathrm{H}), 8.56(\mathrm{~s}, 2 \mathrm{H}), 8.27(\mathrm{~s}, 1 \mathrm{H}), 7.98(\mathrm{~s}, 1 \mathrm{H}), 7.80(\mathrm{~d}, J=6.4 \mathrm{~Hz}$, $1 \mathrm{H}), 2.74(\mathrm{~s}, 3 \mathrm{H}) .{ }^{13} \mathrm{C}\left\{{ }^{1} \mathrm{H}\right\} \mathrm{NMR}\left(101 \mathrm{MHz}, \mathrm{CDCl}_{3}\right) \delta 196.8,155.4,151.3,144.2,140.1,132.3$ $(\mathrm{q}, J=33.7 \mathrm{~Hz}), 123.0,127.1,123.3(\mathrm{q}, J=273.3 \mathrm{~Hz}), 121.4,117.6,26.8$. HRMS (ESI) Calcd for: $\mathrm{C}_{15} \mathrm{H}_{10} \mathrm{NOF}_{6}$ : 334.0661 ; Found: $334.0659[\mathrm{M}+\mathrm{H}]^{+}$.

1-(2-(3-Fluoro-5-(trifluoromethyl)phenyl)pyridin-4-yl)ethan-1-one (20): Following the general procedure using 4-acetylpyridine $(264 \mu \mathrm{L}, 2.4 \mathrm{mmol})$ and 3-fluoro-5(trifluoromethyl)aniline ( $76 \mu \mathrm{L}, 0.6 \mathrm{mmol})$, the residue was purified by flash chromatography on silica gel (heptane-EtOAc, 95-5) to afford the desired compound 20 (76 $\mathrm{mg}, 45 \%$ ) as a yellow solid. ${ }^{1} \mathrm{H}$ NMR (400 MHz, $\left.\mathrm{CDCl}_{3}\right) \delta 8.96(\mathrm{~d}, J=5.0 \mathrm{~Hz}, 1 \mathrm{H}), 8.40(\mathrm{dd}, J=7.1,2.3 \mathrm{~Hz}$, 1H), $8.29(\mathrm{~s}, 1 \mathrm{H}), 7.77(\mathrm{~d}, J=6.6 \mathrm{~Hz}, 1 \mathrm{H}), 7.75-7.68(\mathrm{~m}, 1 \mathrm{H}), 7.39-7.31(\mathrm{~m}, 1 \mathrm{H}), 2.71(\mathrm{~s}$, $3 \mathrm{H}) .{ }^{13} \mathrm{C}\left\{{ }^{1} \mathrm{H}\right\} \quad \mathrm{NMR}\left(101 \mathrm{MHz}, \mathrm{CDCl}_{3}\right) \delta 197.0,162.2(\mathrm{~d}, J=256.2 \mathrm{~Hz}), 153.2(\mathrm{~d}, J=2.5$ $\mathrm{Hz}), 151.1,143.6,128.8$ (q, $J=3.9 \mathrm{~Hz}), 128.1$ (dq, $J=3.6,9.9 \mathrm{~Hz}), 127.3$ (d, $J=12.6 \mathrm{~Hz})$, 123.7 (q, $J=272.1 \mathrm{~Hz}), 122.1$ (d, $J=10.3 \mathrm{~Hz}), 120.7,117.2$ (d, $J=24.6 \mathrm{~Hz}), 26.8$. HRMS (ESI) Calcd for: $\mathrm{C}_{14} \mathrm{H}_{9} \mathrm{NOF}_{4} \mathrm{Na}$ : 306.0513; Found: $306.0515[\mathrm{M}+\mathrm{Na}]^{+}$. 
1-(2-(2-Fluorophenyl)pyridin-4-yl)ethan-1-one (21): Following the general procedure using 4-acetylpyridine $(264 \mu \mathrm{L}, 2.4 \mathrm{mmol})$ and 2-fluoroaniline $(57 \mu \mathrm{L}, 0.6 \mathrm{mmol})$, the residue was purified by flash chromatography on silica gel (heptane-EtOAc, 95-5) to afford the desired compound 21 (44 mg, 34\%) as a yellow solid. ${ }^{1} \mathrm{H}$ NMR (400 MHz, $\left.\mathrm{CDCl}_{3}\right) \delta 8.91(\mathrm{~d}, J=5.0$ $\mathrm{Hz}, 1 \mathrm{H}), 8.24$ (s, 1H), 8.01 (td, $J=7.9,1.7 \mathrm{~Hz}, 1 \mathrm{H}), 7.71(\mathrm{~d}, J=5.0 \mathrm{~Hz}, 1 \mathrm{H}), 7.44-7.41$ (m, 1H), $7.34-7.27(\mathrm{~m}, 1 \mathrm{H}), 7.25-7.17(\mathrm{~m}, 1 \mathrm{H}), 2.68(\mathrm{~s}, 3 \mathrm{H}) .{ }^{13} \mathrm{C}\left\{{ }^{1} \mathrm{H}\right\}$ NMR $\left(101 \mathrm{MHz}, \mathrm{CDCl}_{3}\right)$ $\delta 197.4,160.5(\mathrm{~d}, J=250.1 \mathrm{~Hz}), 154.9,150.8,143.4,131.0(\mathrm{~d}, J=4.6 \mathrm{~Hz}), 131.0(\mathrm{~d}, J=1.1$ $\mathrm{Hz}), 126.8$ (d, $J=11.3 \mathrm{~Hz}), 124.6$ (d, $J=3.6 \mathrm{~Hz}), 122.2$ (d, $J=9.4 \mathrm{~Hz}), 119.8,116.3$ (d, $J=$ 22.9 Hz), 26.8. HRMS (ESI) Calcd for: $\mathrm{C}_{13} \mathrm{H}_{10} \mathrm{NOFNa}$ : 238.0639; Found: 238.0637 [M+Na] .

4,4'-Di-tert-butyl-6-(4-chlorophenyl)-2,2'-bipyridine (22): Following the general procedure using 4,4'-di-tert-butyl-2,2'-bipyridine (634 mg, $2.4 \mathrm{mmol}$ ) and 4-chloroaniline (76 mg, 0.6 mmol), the residue was purified by flash chromatography on silica gel (heptane-EtOAc, 99-1) to afford the desired compound $22(139 \mathrm{mg}, 61 \%)$. ${ }^{1} \mathrm{H}$ NMR $\left(400 \mathrm{MHz}, \mathrm{CDCl}_{3}\right) \delta 8.64(\mathrm{~d}, J=$ $5.3 \mathrm{~Hz}, 1 \mathrm{H}), 8.62(\mathrm{~s}, 1 \mathrm{H}), 8.44(\mathrm{~s}, 1 \mathrm{H}), 8.12(\mathrm{~d}, J=8.6 \mathrm{~Hz}, 2 \mathrm{H}), 7.76(\mathrm{~s}, 1 \mathrm{H}), 7.52$ (d, $J=8.6$ $\mathrm{Hz}, 2 \mathrm{H}), 7.35(\mathrm{~d}, J=4.5 \mathrm{~Hz}, 1 \mathrm{H}), 1.47(\mathrm{~s}, 9 \mathrm{H}), 1.44(\mathrm{~s}, 9 \mathrm{H}) .{ }^{13} \mathrm{C}\left\{{ }^{1} \mathrm{H}\right\}$ NMR $\left(101 \mathrm{MHz}, \mathrm{CDCl}_{3}\right)$ $\delta 161.9,160.8,156.4,156.3,155.2,148.9,138.4,134.8,128.8,128.3,120.8,118.4,117.1$, 117.0, 35.2, 34.9, 30.7, 30.6. HRMS (ESI) Calcd for: $\mathrm{C}_{24} \mathrm{H}_{28} \mathrm{~N}_{2}{ }^{35} \mathrm{Cl}$ : 379.1936; Found: $379.1936[\mathrm{M}+\mathrm{H}]^{+}$.

6-(4-Bromophenyl)-4,4'-di-tert-butyl-2,2'-bipyridine (23): Following the general procedure using 4,4'-di-tert-butyl-2,2'-bipyridine (634 mg, $2.4 \mathrm{mmol}$ ) and 4-bromoaniline (103 mg, 0.6 mmol), the residue was purified by flash chromatography on silica gel (heptane-EtOAc, 99-1) to afford the desired compound $23\left(147 \mathrm{mg}, 58 \%\right.$ ) as a white solid. ${ }^{1} \mathrm{H}$ NMR (400 $\mathrm{MHz}, \mathrm{CDCl}_{3}$ ) $\delta 8.64(\mathrm{~d}, J=5.2 \mathrm{~Hz}, 1 \mathrm{H}), 8.62(\mathrm{~s}, 1 \mathrm{H}), 8.44(\mathrm{~s}, 1 \mathrm{H}), 8.05(\mathrm{~d}, J=8.5 \mathrm{~Hz}, 2 \mathrm{H}), 7.75(\mathrm{~s}, 1 \mathrm{H}), 7.67$ $(\mathrm{d}, J=8.5 \mathrm{~Hz}, 2 \mathrm{H}), 7.35(\mathrm{~d}, J=5.2 \mathrm{~Hz}, 1 \mathrm{H}), 1.47(\mathrm{~s}, 9 \mathrm{H}), 1.44(\mathrm{~s}, 9 \mathrm{H}) .{ }^{13} \mathrm{C}\left\{{ }^{1} \mathrm{H}\right\}$ NMR $(101$ $\left.\mathrm{MHz}, \mathrm{CDCl}_{3}\right) \delta 161.9,160.9,156.4,156.2,155.3,148.9,138.9,131.8,128.6,123.1,120.8$, 118.4 117.1, 117.1, 35.2, 34.9, 30.7, 30.6. HRMS (ESI) Calcd for: $\mathrm{C}_{24} \mathrm{H}_{27} \mathrm{~N}_{2}{ }^{79} \mathrm{BrNa}$ : 445.1250; Found: $445.1250[\mathrm{M}+\mathrm{Na}]^{+}$.

4,4'-di-tert-butyl-6-(3-fluoro-5-(trifluoromethyl)phenyl)-2,2'-bipyridine (24): Following the general procedure using 4,4'-di-tert-butyl-2,2'-bipyridine (634 mg, $2.4 \mathrm{mmol}$ ) and 3-fluoro5-(trifluoromethyl)aniline ( $76 \mu \mathrm{L}, 0.6 \mathrm{mmol})$, the residue was purified by flash chromatography on silica gel (heptane-EtOAc, 99-1) to afford the desired compound $\mathbf{2 4}(116 \mathrm{mg}, 45 \%)$ as a yellow solid. ${ }^{1} \mathrm{H}$ NMR $\left(400 \mathrm{MHz}, \mathrm{CDCl}_{3}\right) \delta 8.65(\mathrm{~d}, J=5.2 \mathrm{~Hz}, 1 \mathrm{H}), 8.62-8.60(\mathrm{~m}, 2 \mathrm{H}), 8.48$ 
(s, 1H), $7.91(\mathrm{~s}, 1 \mathrm{H}), 7.71-7.67(\mathrm{~m}, 1 \mathrm{H}), 7.38-7.31(\mathrm{~m}, 2 \mathrm{H}), 1.47(\mathrm{~s}, 9 \mathrm{H}), 1.43(\mathrm{~s}, 9 \mathrm{H})$. ${ }^{13} \mathrm{C}\left\{{ }^{1} \mathrm{H}\right\} \operatorname{NMR}\left(101 \mathrm{MHz}, \mathrm{CDCl}_{3}\right) \delta 162.4(\mathrm{~d}, J=254.6 \mathrm{~Hz}), 161.9,161.0,156.4,156.2,150.7$ (d, $J=3.0 \mathrm{~Hz}), 149.0,129.1$ (q, $J=4.1 \mathrm{~Hz}), 128.5$ (d, $J=12.5 \mathrm{~Hz}), 127.3$ - 126.9 (m), 123.9 $(\mathrm{q}, J=272.0 \mathrm{~Hz}), 121.5(\mathrm{~d}, J=10.4 \mathrm{~Hz}), 121.0,118.4,117.5,117.0(\mathrm{~d}, J=24.9 \mathrm{~Hz}), 25.2,35.0$, 30.7, 30.5. HRMS (ESI) Calcd for: $\mathrm{C}_{25} \mathrm{H}_{27} \mathrm{~N}_{2} \mathrm{~F}_{4}$ : 431.2105; Found: $431.2105[\mathrm{M}+\mathrm{H}]^{+}$.

6-(4-Bromophenyl)-4,4'-dimethyl-2,2'-bipyridine (25): Following the general procedure using 4,4'-dimethyl-2,2'-bipyridine (442 mg, $2.4 \mathrm{mmol}$ ) and 4-bromoaniline (103 mg, 0.6 mmol), the residue was purified by flash chromatography on silica gel (heptane-EtOAc, 98-2) to afford the desired compound 25 (98 mg, 48\%). ${ }^{1} \mathrm{H}$ NMR (400 MHz, $\left.\mathrm{CDCl}_{3}\right) \delta 8.57(\mathrm{~d}, J=$ $4.9 \mathrm{~Hz}, 1 \mathrm{H}), 8.42(\mathrm{~s}, 1 \mathrm{H}), 8.24(\mathrm{~s}, 1 \mathrm{H}), 8.04(\mathrm{~d}, J=8.5 \mathrm{~Hz}, 2 \mathrm{H}), 7.65(\mathrm{~d}, J=8.5 \mathrm{~Hz}, 2 \mathrm{H}), 7.57$ $(\mathrm{s}, 1 \mathrm{H}), 7.17(\mathrm{~d}, J=4.3 \mathrm{~Hz}, 1 \mathrm{H}), 2.52(\mathrm{~s}, 3 \mathrm{H}), 2.50(\mathrm{~s}, 3 \mathrm{H}) .{ }^{13} \mathrm{C}\left\{{ }^{1} \mathrm{H}\right\}$ NMR $\left(101 \mathrm{MHz}, \mathrm{CDCl}_{3}\right)$ $\delta 156.0,155.8,155.3,148.9,148.8,148.1,138.4,131.8,128.6,124.7,123.2,122.1,121.0$, 120.7, 21.4, 21.3. HRMS (ESI) Calcd for: $\mathrm{C}_{18} \mathrm{H}_{15} \mathrm{~N}_{2}{ }^{79} \mathrm{BrNa}$ : 361.0311; Found: 361.0312 $[\mathrm{M}+\mathrm{Na}]^{+}$.

\section{ASSOCIATED CONTENT}

The Supporting Information is available free of charge on the ACS Publications website. ${ }^{1} \mathrm{H}$ and ${ }^{13} \mathrm{C}$ NMR spectra for all new compounds. Details for tempo-trapping and KIE experiments.

\section{AUTHOR INFORMATION}

\section{Corresponding Author}

jean-francois.soule@univ-rennes1.fr

\section{ACKNOWLEDGMENT}

Financial support from CNRS, Univ. Rennes 1, Rennes Métropole, and Région Bretagne (Boost'Europe 18003332) is acknowledged.

\section{REFERENCES}

1. a. Douglas, J. J.; Sevrin, M. J.; Stephenson, C. R. J., Visible Light Photocatalysis: Applications and New Disconnections in the Synthesis of Pharmaceutical Agents. Org. Process Res. Dev. 2016, 20, 1134-1147; b. Shaw, M. H.; Twilton, J.; MacMillan, D. W. C., Photoredox Catalysis in Organic Chemistry. J. Org. Chem. 2016, 81, 6898-6926; c. Tóth, B. 
L.; Tischler, O.; Novák, Z., Recent Advances in Dual Transition Metal-Visible Light Photoredox Catalysis. Tetrahedron Lett. 2016, 57, 4505-4513.

2. Lamansky, S.; Djurovich, P.; Murphy, D.; Abdel-Razzaq, F.; Lee, H.-E.; Adachi, C.; Burrows, P. E.; Forrest, S. R.; Thompson, M. E., Highly Phosphorescent BisCyclometalated Iridium Complexes: Synthesis, Photophysical Characterization, and Use in Organic Light Emitting Diodes. J. Am. Chem. Soc. 2001, 123, 4304-4312.

3. a. Alves, T.; De Oliveira, A. B.; Snieckus, V., Short Synthesis of Azafluorenone Alkaloids using Transition Metal-Catalyzed Cross Coupling Tactics. Tetrahedron Lett. 1988, 29, 2135-2136; b. Bonnet, V.; Mongin, F.; Trecourt, F.; Queguiner, G.; Knochel, P., Preparation of Polyfunctional Pyridines by a Palladium(0)-Catalyzed Cross-Coupling of Functionalized Aryl Grignard Reagents. Tetrahedron Lett. 2001, 42, 5717-5719; c. Bonnet, V.; Mongin, F.; Trecourt, F.; Queguiner, G.; Knochel, P., Syntheses of Substituted Pyridines, Quinolines and Diazines via Palladium-Catalyzed Cross-Coupling of aryl Grignard Reagents. Tetrahedron 2002, 58, 4429-4438; d. Gauthier, D. R., Jr.; Szumigala, R. H., Jr.; Dormer, P. G.; Armstrong, J. D., III; Volante, R. P.; Reider, P. J., Synthesis of 5-Pyridyl-2furaldehydes via Palladium-Catalyzed Cross-Coupling with Triorganozincates. Org. Lett. 2002, 4, 375-378; e. Negishi, E.-i.; Takahashi, T.; King, A. O., Synthesis of Biaryls via Palladium-Catalyzed Cross Coupling: 2-Methyl-4'-Nitrobiphenyl. Org. Synth. 1988, 66, 6774; f. Sibille, S.; Ratovelomanana, V.; Nedelec, J. Y.; Perichon, J., An Efficient Route to Unsymmetrical Biaryls via the Electrochemical Preparation of Functionalized Aromatic Zinc Organometallics. Synlett 1993, 425-426; g. Su, W.; Urgaonkar, S.; Verkade, J. G., $\mathrm{Pd} 2(\mathrm{dba}) 3 / \mathrm{P}(\mathrm{i}-\mathrm{BuNCH} 2 \mathrm{CH} 2) 3 \mathrm{~N}-\mathrm{Catalyzed} \mathrm{Stille} \mathrm{Cross-Coupling} \mathrm{of} \mathrm{Aryl} \mathrm{Chlorides.} \mathrm{Org.}$ Lett. 2004, 6, 1421-1424; h. Wolf, C.; Lerebours, R., Efficient Stille Cross-Coupling Reaction Using Aryl Chlorides or Bromides in Water. J. Org. Chem. 2003, 68, 7551-7554.

4. a. Beley, M.; Chodorowski, S.; Collin, J. P.; Sauvage, J. P., Synthesis of Biscyclometallating N-C-N Hexadentate Ligands via C-C Aromatic Couplings and Their Dinuclear Ruthenium(II) Complexes. Tetrahedron Lett. 1993, 34, 2933-2936; b. Choppin, S.; Gros, P.; Fort, Y., Unusual C-6 Lithiation of 2-Chloropyridine-Mediated by BuLi$\mathrm{Me} 2 \mathrm{~N}(\mathrm{CH} 2) 2 \mathrm{OLi}$. New Access to 6-Functional-2-chloropyridines and Chloro-bisheterocycles. Org. Lett. 2000, 2, 803-805; c. Gronowitz, S.; Bjoerk, P.; Malm, J.; Hoernfeldt, A.-B., The Effect of Some Additives on the Stille Pd0-Catalyzed Cross-Coupling Reaction. J. Organomet. Chem. 1993, 460, 127-129; d. Lam, F.; Chan, K. S., Synthesis of Acyclic Dinucleating Schiff Base-Pyridine and Schiff Base-Phosphine Ligands. Tetrahedron Lett. 1995, 36, 919-922; e. Lorthiois, E.; Bernardelli, P.; Vergne, F.; Oliveira, C.; Mafroud, A.K.; Proust, E.; Heuze, L.; Moreau, F.; Idrissi, M.; Tertre, A.; Bertin, B.; Coupe, M.; Wrigglesworth, R.; Descours, A.; Soulard, P.; Berna, P., Spiroquinazolinones as Novel, Potent, and Selective PDE7 Inhibitors. Part 1. Bioorg. Med. Chem. Lett. 2004, 14, 4623-4626; f. Rashkin, M. J.; Waters, M. L., Unexpected Substituent Effects in Offset $\pi-\pi$ Stacked Interactions in Water. J. Am. Chem. Soc. 2002, 124, 1860-1861; g. Wilkinson, A. J.; Puschmann, H.; Howard, J. A. K.; Foster, C. E.; Williams, J. A. G., Luminescent Complexes of Iridium(III) Containing N,C,N-Coordinating Terdentate Ligands. Inorg. Chem. 2006, 45, 8685-8699; h. Williams, J. A. G.; Beeby, A.; Davies, E. S.; Weinstein, J. A.; Wilson, C., An Alternative Route to Highly Luminescent Platinum(II) Complexes: Cyclometalation with NC-N-Coordinating Dipyridylbenzene Ligands. Inorg. Chem. 2003, 42, 8609-8611. 
5. a. Godula, K.; Sezen, B.; Sames, D., Site-Specific Phenylation of Pyridine Catalyzed by Phosphido-Bridged Ruthenium Dimer Complexes: A Prototype for $\mathrm{C}-\mathrm{H}$ Arylation of Electron-Deficient Heteroarenes. J. Am. Chem. Soc. 2005, 127, 3648-3649; b. Hagui, W.; Besbes, N.; Srasra, E.; Soulé, J.-F.; Doucet, H., Direct access to 2-(hetero)arylated pyridines from 6-substituted 2-bromopyridines via phosphine-free palladium-catalyzed $\mathrm{C}-\mathrm{H}$ bond arylations: the importance of the C6 substituent. RSC Advances 2016, 6, 17110-17117.

6. a. Shen, Y.; Chen, J.; Liu, M.; Ding, J.; Gao, W.; Huang, X.; Wu, H., CopperCatalyzed Direct C-H Arylation of Pyridine N-Oxides with Arylboronic Esters: One-Pot Synthesis of 2-Arylpyridines. Chem. Commun. 2014, 50, 4292-4295; b. Dabiri, M.; Alavioon, S. I.; Movahed, S. K., Decarboxylative Arylation of Pyridine 1-Oxides and Anilides with Benzoic Acid via Palladium-Catalyzed C-H Functionalization. Eur. J. Org. Chem. 2019, 2019, 1479-1487; c. Dabiri, M.; Alavioon, S. I.; Movahed, S. K., Palladium Supported on Mesoporous Silica/Graphene Nanohybrid as a Highly Efficient and Reusable Heterogeneous Catalyst for $\mathrm{C}-\mathrm{H}$ Functionalization. ChemistrySelect 2018, 3, 3487-3494; d. Roudesly, F.; Veiros, L. F.; Oble, J.; Poli, G., Pd-Catalyzed Direct C-H Alkenylation and Allylation of Azine N-Oxides. Org. Lett. 2018, 20, 2346-2350.

7. Wang, C.-S.; Dixneuf, P. H.; Soulé, J.-F., Photoredox Catalysis for Building C-C Bonds from C(sp2)-H Bonds. Chem. Rev. 2018, 118, 7532-7585.

8. Xue, D.; Jia, Z.-H.; Zhao, C.-J.; Zhang, Y.-Y.; Wang, C.; Xiao, J., Direct Arylation of N-Heteroarenes with Aryldiazonium Salts by Photoredox Catalysis in Water. Chem. Eur. J. 2014, 20, 2960-2965.

9. a. Zhang, J.; Chen, J.; Zhang, X.; Lei, X., Total Syntheses of Menisporphine and Daurioxoisoporphine C Enabled by Photoredox-Catalyzed Direct C-H Arylation of Isoquinoline with Aryldiazonium Salt. J. Org. Chem. 2014, 79, 10682-10688; b. Gomes, F.; Narbonne, V.; Blanchard, F.; Maestri, G.; Malacria, M., Formal Base-Free Homolytic Aromatic Substitutions via Photoredox Catalysis. Org. Chem. Front. 2015, 2, 464-469; c. Zhi, L.; Zhang, H.; Yang, Z.; Liu, W.; Wang, B., Interface Coassembly of Mesoporous MoS2 Based-Frameworks for Enhanced Near-Infrared Light Driven Photocatalysis. Chem. Commun. 2016, 52, 6431-6434; d. Buglioni, L.; Riente, P.; Palomares, E.; Pericas, M. A., Visible-Light-Promoted Arylation Reactions Photocatalyzed by Bismuth(III) Oxide. Eur. J. Org. Chem. 2017, 2017, 6986-6990; e. Crespi, S.; Jaeger, S.; Koenig, B.; Fagnoni, M., A Photocatalytic Meerwein Approach to the Synthesis of Isochromanones and Isochromenones. Eur. J. Org. Chem. 2017, 2017, 2147-2153; f. Fabry, D. C.; Ho, Y. A.; Zapf, R.; Tremel, W.; Panthoefer, M.; Rueping, M.; Rehm, T. H., Blue Light Mediated C-H Arylation of Heteroarenes using TiO2 as an Immobilized Photocatalyst in a Continuous-Flow Microreactor. Green Chem. 2017, 19, 1911-1918; g. Zhang, S.; Tang, Z.; Bao, W.; Li, J.; Guo, B.; Huang, S.; Zhang, Y.; Rao, Y., Perylenequinonoid-Catalyzed Photoredox Activation for the Direct Arylation of (Het)arenes with Sunlight. Org. Biomol. Chem. 2019, 17, 4364-4369; h. Vardhanapu, P. K.; Ahmed, J.; Jose, A.; Shaw, B. K.; Sen, T. K.; Mathews, A. A.; Mandal, S. K., Phenalenyl Based Aluminum Compound for Catalytic C-H Arylation of Arene and Heteroarenes at Room Temperature. J. Org. Chem. 2019, 84, 289299. 
10. Fürst, M. C. D.; Gans, E.; Böck, M. J.; Heinrich, M. R., Visible - Light - Induced, Catalyst - Free Radical Arylations of Arenes and Heteroarenes with Aryldiazonium Salts. Chem. Eur. J. 2017, 23, 15312-15315.

11. Lima, C. G. S.; de M. Lima, T.; Duarte, M.; Jurberg, I. D.; Paixão, M. W., Organic Synthesis Enabled by Light-Irradiation of EDA Complexes: Theoretical Background and Synthetic Applications. ACS Catal. 2016, 6, 1389-1407.

12. Crisóstomo, F. P.; Martín, T.; Carrillo, R., Ascorbic Acid as an Initiator for the Direct C-H Arylation of (Hetero)arenes with Anilines Nitrosated In Situ. Angew. Chem. Int. Ed. 2014, 53, 2181-2185.

13. Monzón, D. M.; Santos, T.; Pinacho-Crisóstomo, F.; Martín, V. S.; Carrillo, R., Mild-Base-Promoted Arylation of (Hetero)Arenes with Anilines. Chem. Asian J. 2018, 13, 325-333.

14. Hata, D.; Moriuchi, T.; Hirao, T.; Amaya, T., Polyaniline-Induced Arylation with Arenediazonium Salts Derived from Anilines. Chem. Eur. J. 2017, 23, 7703-7709.

15. Colleville, A. P.; Horan, R. A. J.; Olazabal, S.; Tomkinson, N. C. O., C-H Arylation of Heterocyclic N-Oxides Through in Situ Diazotisation Of Anilines without Added

Promoters: A Green And Selective Coupling Process. Org. Process Res. Dev. 2016, 20, 1283 1296.

16. Cantillo, D.; Mateos, C.; Rincon, J. A.; de Frutos, O.; Kappe, C. O., Light-Induced C-H Arylation of (Hetero)arenes by In Situ Generated Diazo Anhydrides. Chem. Eur. J. 2015, 21, 12894-12898.

17. Tauber, J.; Imbri, D.; Opatz, T., Radical Addition to Iminium Ions and Cationic Heterocycles. Molecules 2014, 19, 16190-16222.

18. Proctor, R. S. J.; Phipps, R. J., Recent Advances in Minisci-Type Reactions. Angew. Chem. Int. Ed. 2019, 58, 13666-13699.

19. a. Hebbe-Viton, V.; Desvergnes, V.; Jodry, J. J.; Dietrich-Buchecker, C.; Sauvage, J.-P.; Lacour, J., Chiral Spiro Cu(I) Complexes. Supramolecular Stereocontrol and Isomerization Dynamics by the Use of TRISPHAT Anions. Dalton Trans. 2006, 2058-2065; b. Zou, C.; Lin, J.; Suo, S.; Xie, M.; Chang, X.; Lu, W., Palladium(II) N-Heterocyclic Allenylidene Complexes with Extended Intercationic Pd $\cdots$ Pd Interactions and MMLCT Phosphorescence. Chem. Commun. 2018, 54, 5319-5322.

20. a. Hyodo, I.; Tobisu, M.; Chatani, N., Catalytic Arylation of a C-H Bond in Pyridine and Related Six-Membered N-Heteroarenes Using Organozinc Reagents. Chem. Asian J. 2012, 7, 1357-1365; b. Tobisu, M.; Hyodo, I.; Chatani, N., Nickel-Catalyzed Reaction of Arylzinc Reagents with N-Aromatic Heterocycles: A Straightforward Approach to C-H Bond Arylation of Electron-Deficient Heteroaromatic Compounds. J. Am. Chem. Soc. 2009, 131, 12070-12071; c. Ilangovan, A.; Polu, A.; Satish, G., K2S2O8-Mediated Metal-Free direct C- 
H Functionalization of Quinones using Arylboronic Acids. Org. Chem. Front. 2015, 2, 16161620.

21. Mkhalid, I. A. I.; Coventry, D. N.; Albesa-Jove, D.; Batsanov, A. S.; Howard, J. A. K.; Perutz, R. N.; Marder, T. B., Ir-Catalyzed Borylation of C-H Bonds in N-Containing Heterocycles: Regioselectivity in the Synthesis of Heteroaryl Boronate Esters. Angew. Chem. Int. Ed. 2006, 45, 489-491.

22. Felipe-Blanco, D.; Alonso, F.; Gonzalez-Gomez, J. C., Salicylic Acid-Catalyzed OnePot Hydrodeamination of Aromatic Amines by tert-Butyl Nitrite in Tetrahydrofuran. $A d v$. Synth. Catal. 2017, 359, 2857-2863.

23. Simmons, E. M.; Hartwig, J. F., On the Interpretation of Deuterium Kinetic Isotope Effects in $\mathrm{C}-\mathrm{H}$ Bond Functionalizations by Transition-Metal Complexes. Angew. Chem. Int. Ed. 2012, 51, 3066-3072.

24. a. Cano-Yelo, H.; Deronzier, A., Photocatalysis of the Pschorr Reaction by tris-(2,2'bipyridyl)ruthenium(II) in the Phenanthrene Series. J. Chem. Soc., Perkin Trans. 2 1984, 1093-1098; b. Cano-Yelo, H.; Deronzier, A., Photocatalysis of the Pschorr Reaction by Ru(bpy)32+. J. Photochem. 1987, 37, 315-321.

25. Li, Y.; Liu, W.; Kuang, C., Direct Arylation of Pyridines without the Use of a Transition Metal Catalyst. Chem. Commun. 2014, 50, 7124-7127.

26. Srinivasulu, A.; Shantharjun, B.; Vani, D.; Ashalu, K. C.; Mohd, A.; WencelDelord, J.; Colobert, F.; Reddy, K. R., Iron-Catalyzed Minisci Type Acetylation of NHeteroarenes Mediated by CH(OEt)3/TBHP. Eur. J. Org. Chem. 2019, 2019, 1815-1819.

27. Prajapati, D.; Schulzke, C.; Kindermann, M. K.; Kapdi, A. R., Selective PalladiumCatalysed Arylation of 2,6-Dibromopyridine using $N$-Heterocyclic Carbene Ligands. $R S C$ Advances 2015, 5, 53073-53085.

28. Sim, J.; Viji, M.; Rhee, J.; Jo, H.; Cho, S. J.; Park, Y.; Seo, S.-Y.; Jung, K.-Y.; Lee, H.; Jung, J.-K., $\gamma$-Functionalization of $\alpha, \beta$-Unsaturated Nitriles under Mild Conditions: Versatile Synthesis of 4-Aryl-2-Bromopyridines. Adv. Synth. Catal. 2019, 361, 5458-5465.

29. Rao, M. L. N.; Dhanorkar, R. J., Triarylbismuthanes as Threefold Aryl-Transfer Reagents in Regioselective Cross-Coupling Reactions with Bromopyridines and Quinolines. Eur. J. Org. Chem. 2014, 2014, 5214-5228. 